Click

Here

Full

Article

\title{
Three-dimensional seismic investigations of the Sevastopol mud volcano in correlation to gas/fluid migration pathways and indications for gas hydrate occurrences in the Sorokin Trough (Black Sea)
}

\section{Wagner-Friedrichs}

Department of Geosciences, University of Bremen, Klagenfurter Strasse, D-28359 Bremen, Germany (miwagner@uni-bremen.de)

Now at FUGRO OSAE, Fahrenheitstrasse 7, D-28359 Bremen, Germany

\section{S. Krastel}

Department of Geosciences, University of Bremen, Klagenfurter Strasse, D-28359 Bremen, Germany

Now at IFM-GEOMAR, Wischhofstrasse 1-3, D-24148 Kiel, Germany

\section{Spiess}

Department of Geosciences, University of Bremen, Klagenfurter Strasse, D-28359 Bremen, Germany

\section{Ivanov}

UNESCO Center for Marine Geosciences, Faculty of Geology, Moscow State University, Vorobjevi Gory, 119899 Moscow, Russia

\section{G. Bohrmann}

Department of Geosciences, University of Bremen, Klagenfurter Strasse, D-28359 Bremen, Germany

\section{Meisner}

Marine Geology and Hydrocarbon Potential Department, SSC "Yuzhmorgeologiya," Krymskaja Str. 18, 353470 Gelendzhik, Russia

[1] New 3-D seismic investigations carried out across the Sevastopol mud volcano in the Sorokin Trough present 3-D seismic data of a mud volcano in the Black Sea for the first time. The studies allow us to image the complex three-dimensional morphology of a collapse structured mud volcano and to propose an evolution model. The Sevastopol mud volcano is located above a buried diapiric structure with two ridges and controlled by fluid migration along a deep fault system, which developed during the growth of the diapirs in a compressional tectonic system. Overpressured fluids initiated an explosive eruption generating the collapse depression of the Sevastopol mud volcano. Several cones were formed within the depression by subsequent quiet mud extrusions. Although gas hydrates have been recovered at various mud volcanoes in the Sorokin Trough, no gas hydrates were sampled at the Sevastopol mud volcano. A BSR (bottomsimulating reflector) is missing in the seismic data; however, high-amplitude reflections (bright spots) observed above the diapiric ridge near the mud volcano at a relatively constant depth correspond to the approximate depth of the base of the gas hydrate stability zone (BGHSZ). Thus we suggest that gas hydrates are present locally where gas/fluid flow occurs related to mud volcanism, i.e., above the diapir and close to the feeder channel of the mud volcano. Depth variations of the bright spots of up to $200 \mathrm{~ms}$ TWT might be caused by temperature variations produced by variable fluid flow. 
Components: 10,893 words, 15 figures.

Keywords: mud volcanoes; gas hydrates; fluid migration; Black Sea; 3-D seismic.

Index Terms: 3004 Marine Geology and Geophysics: Gas and hydrate systems; 3025 Marine Geology and Geophysics: Marine seismics (0935, 7294); 8426 Volcanology: Mud volcanism.

Received 10 May 2007; Revised 15 August 2007; Accepted 21 November 2007; Published 15 May 2008.

Wagner-Friedrichs, M., S. Krastel, V. Spiess, M. Ivanov, G. Bohrmann, and L. Meisner (2008), Three-dimensional seismic investigations of the Sevastopol mud volcano in correlation to gas/fluid migration pathways and indications for gas hydrate occurrences in the Sorokin Trough (Black Sea), Geochem. Geophys. Geosyst., 9, Q05012, doi:10.1029/2007GC001685.

\section{Introduction}

[2] Mud volcanoes are structures related to fluid discharge and are considered to be one of the most significant natural sources of carbon emission to the hydrosphere and atmosphere [e.g., Dimitrov, 2003]. Emission is dominated by methane gas, which contributes to the modern atmospheric methane budget [Dimitrov, 2003; Milkov et al., 2003]. The emitted greenhouse gases have a great relevance to the carbon budget and climatic change, which has increased interest in mud volcanoes in the last decades [e.g., Milkov, 2000]. Mud volcanoes are formed by the expulsion of gas, water and sediments, which might occur during violent eruptions, but mostly occur by semiliquid effusive mudflows [Dimitrov, 2002; Milkov et al., 2003]. Thus the extruded material at mud volcanoes contains information about sediments and fluids in the shallow and deep subsurface [e.g., Guliyev and Feizullayev, 1997]. Estimates about the amount of methane emitted to the atmosphere through mud volcanoes vary significantly: Milkov et al. [2003] establish that the global methane flux through mud volcanoes is about $\sim 33 \mathrm{Tg} \mathrm{a}^{-1}$, while Kopf [2002] suggests that only $0.08-1.41 \mathrm{Tg} \mathrm{a}^{-1}$ of methane are released through mud volcanoes. Dimitrov [2003] estimates that the annual amount of methane released from onshore and shallow water mud volcanoes ranges between $10.2-12.6 \mathrm{Tg}$. Mud volcanoes occur worldwide onshore and offshore, predominantly in areas of compressive tectonic regimes facilitating fluid/gas and mudflow to the surface [Kopf, 2002]. Almost 2000 mud volcanoes have been observed worldwide, most located along the Alpine-Himalaya Active Belt [Dimitrov, 2003]. The distribution, activity, eruption products and formation mechanisms of terrestrial mud volcanoes have been well studied for over 200 years. The investigation of submarine mud volcanoes, however, only started $\sim 30$ years ago and the exact number of submarine mud volcanoes is uncertain, but the number of described submarine mud volcanoes is increasing rapidly [Dimitrov, 2003]. The formation of mud volcanoes has been intensively discussed and is affected by several factors and processes. Woodside et al. [1997] distinguished two main mechanisms for the formation of mud volcanoes: (1) fluid migration associated with a shale diapir and (2) rise of fluidized mud along faults and fractures. Mud volcanoes show a great variety in size and geometry [Kopf, 2002]. Morphological and structural characteristics of submarine mud volcanoes are mainly investigated by hydroacoustic methods, such as seismic and side-scan sonar investigations. The morphology of mud volcanoes reflects the eruption style and the physical properties of eruption material directly, which primarily depend on the fluid content, the viscosity and consolidation of the extruded mud [Brown, 1990; Kopf, 2002].

[3] The Black Sea contains thick sedimentary sequences with high methane concentrations. It provides an excellent area to study mud volcanism. Well studied mud volcanoes occur in the central part of the Black Sea [Ivanov et al., 1996; Limonov et al., 1997] and in the Sorokin Trough [Ginsburg et al., 1990; Woodside et al., 1997; Krastel et al., 2003]. The mud volcanoes in the Sorokin Trough show varying morphology and are generally connected to near-subsurface diapiric structures [Woodside et al., 1997]. The evolution of the mud volcanoes in the Sorokin Trough is primarily linked to faults acting as migration pathways for rising fluidized mud [Woodside et al., 1997]. Generally, deep water mud volcanoes are often associated with gas hydrate occurrences [Woodside et al., 1997] as first discussed by Ginsburg et al. [1984]. In the Sorokin Trough gas hydrates near numerous mud volcanoes have been sampled since the 1980s [e.g., Ginsburg et al., 1990; Ivanov et al., 


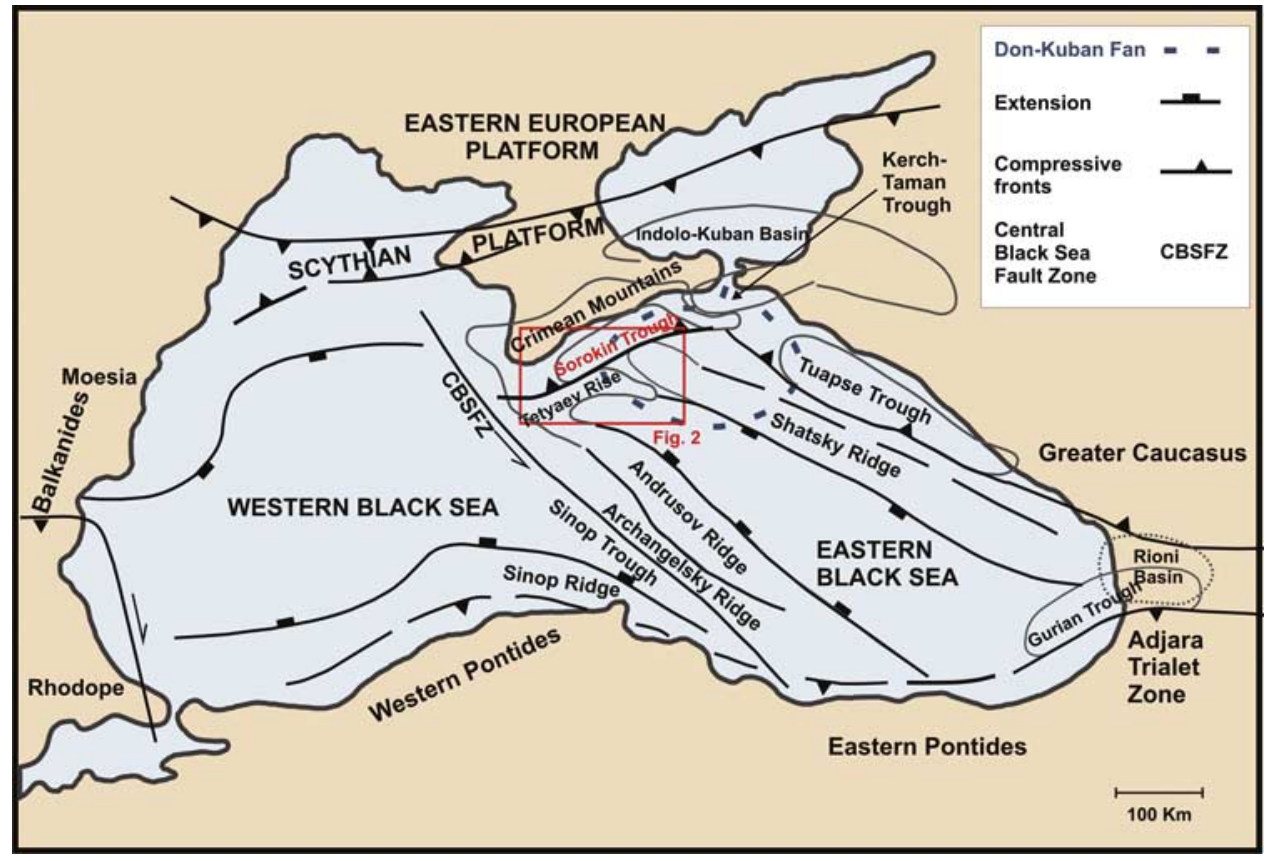

Figure 1. Schematic map of the Black Sea showing the major tectonic units, morphological structures and the location of the study area (Sorokin Trough), highlighted in red (modified after Robinson et al. [1996], copyright 1996, with permission from Elsevier). The grey lines mark the borders of the morphological structures.

1998; Bohrmann et al., 2003], but no BSRs have been identified on seismic sections.

[4] During Meteor cruise M52/1 in January 2002, a high-resolution three-dimensional seismic survey was carried out in the vicinity of the Sevastopol mud volcano in order to obtain the detailed spatial geometry of a collapse structured mud volcano and its subsurface structures, which provide an evolution model directly related to gas/fluid migration along deep faults. The main objectives of this survey have been focused on the following aims and questions: (1) What is the three-dimensional morphological structure of the Sevastopol mud volcano? (2) What kind of subsurface structures are associated with the mud volcano? (3) What conclusions about the evolution and eruption style of the mud volcano can be drawn from the identified surface and subsurface structures? (4) What are the main fluid/gas migration pathways controlling the formation of the mud volcano? (5) Is there evidence for gas hydrate in the surroundings of the mud volcano?

\section{Geological Setting}

[5] The Black Sea, surrounded by Late Cenozoic mountain belts (the Pontides, the Caucasus, Southern Crimea and the Balkanides), is the world's largest anoxic intercontinental basin. The Black Sea presumably originated as a back-arc basin related to the subduction of the Thetyan Ocean during the Late Cretaceous [Dewey et al., 1973; Finetti et al., 1988; Nikishin et al., 2003]. Because of the collision between the Eurasian and the Arabian plates since the Eocene, the tectonic setting changed to a compressional regime [Nikishin et al., 2003]. Structurally, the Black Sea is composed of two basins, the Western Black Sea Basin and the Eastern Black Sea Basin, which are separated by the Androusov Ridge (Figure 1) consisting of continental crust and overlain by $5-6 \mathrm{~km}$ of sediments [Tugolesov et al., 1985]. The timing of the origin and formation of the basins are still under debate [e.g., Okay et al., 1994; Rangin et al., 2002]. Currently, it is widely accepted that the Western Black Sea Basin opened in the MidCretaceous, which is based on stratigraphic evidence from the northern Black Sea margin [e.g., Robinson et al., 1996]. The age of the opening in the Eastern Black Sea is not as well documented and interpretations vary from the Jurassic [Golmshtok et al., 1992], to End-Cretaceous [Nikishin et al., 2003] and Paleocene/Eocene opening [Robinson et al., 1996; Spadini et al., 1996; Cloething et al., 2003]. The Western Basin is thought to be underlain by oceanic crust with a sediment cover of up to $19 \mathrm{~km}$ thickness [Tugolesov et al., 1985]. The basement of 


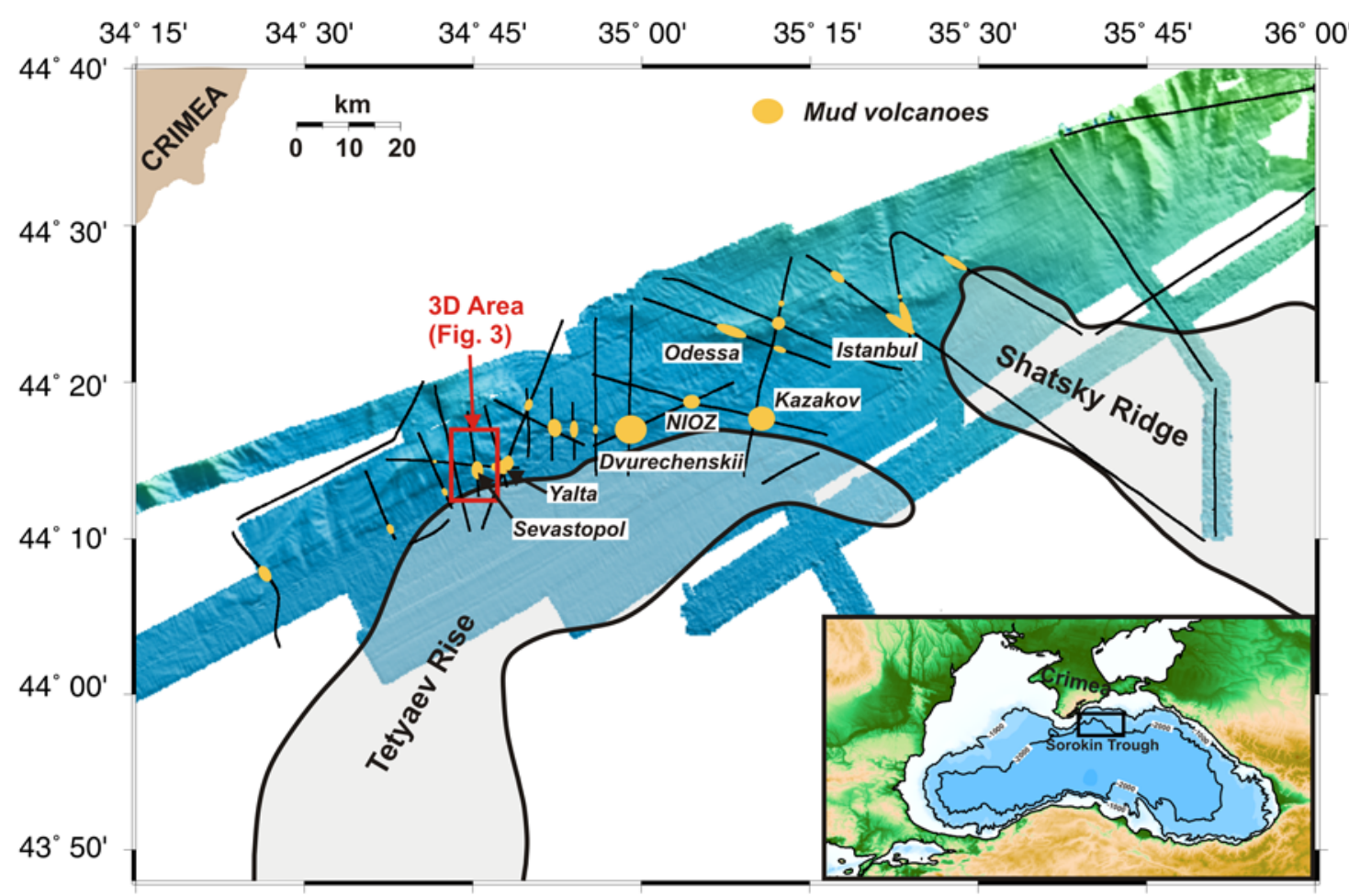

Figure 2. Bathymetric map of the Sorokin Trough together with the location of the seismic overview profiles (continuous lines) and the area of the 3-D survey (red rectangle). The yellow circles show the location of the mud volcanoes observed during Meteor cruise M52/1.

the Eastern Basin is thinned and it is still discussed whether it represents oceanic [Finetti et al., 1988; Belousov et al., 1988; Rangin et al., 2002] or continental crust [Tugolesov et al., 1985]. The crust in the Eastern Basin, however, is overlain by up to $12 \mathrm{~km}$ thick postrift sediments [Tugolesov et al., 1985; Rangin et al., 2002].

[6] The Sorokin Trough (Figures 1 and 2) forms a $150 \mathrm{~km}$ long and $50 \mathrm{~km}$ wide structural depression along the southeastern margin of the Crimean Peninsula in the Eastern Black Sea Basin at water depths of 800-2200 m [Tugolesov et al., 1985]. The trough is considered to be a foredeep of the Crimean Mountains and belongs to a system of Oligocene-Miocene troughs, such as the KerchTaman Trough and Indolo-Kuban Basin (Figure 1) [Tugolesov et al., 1985]. In the south and southeast, the Sorokin Trough is bordered by the buried Cretaceous-Eocene Shatsky Ridge and Tetyaev Rise (Figures 1 and 2). The formation of the Sorokin Trough began during the Oligocene with the Crimean-Alpine folding [Andreev, 1976].

[7] On the basis of seismic data, two main units have been recognized in the sedimentary cover of the Sorokin Trough [Woodside et al., 1997]:
The lower unit consists of the upper part of the Maikopian Formation (Oligocene-lower Miocene) and Pliocene deposits. It is intensively folded and disturbed by numerous faults, which can be traced into the upper unit. The thickness of the unit varies from 5 to $6 \mathrm{~km}$. The upper unit consists of Quaternary deposits, which are characterized by subparallel bedding, forming a blanket above the lower unit [Limonov et al., 1997]. The Quaternary deposits can be laterally subdivided into fan deposits of the Pleistocene palaeo Don-Kuban Fan and basinal deposits, consisting of hemipelagic sediments and turbidites with an origin in the Crimean Mountains. The thickness of the unit is controlled by the underlying diapirs and varies from several $100 \mathrm{~m}$ to up to $2 \mathrm{~km}$, but generally increases toward the northeast [Limonov et al., 1997]. A compressional tectonic regime, produced by the northward movements of the Shatsky Ridge and the Tetyaev Rise, and the weight of the overburden affect the protrusion of water-saturated clay of the Maikopian Formation and lead to the growth of diapiric structures [Limonov et al., 1997]. The diapiric ridges mainly strike in the E-W direction, but the strike direction changes eastward and westward to follow the trends of the buried Tetyaev Rise 


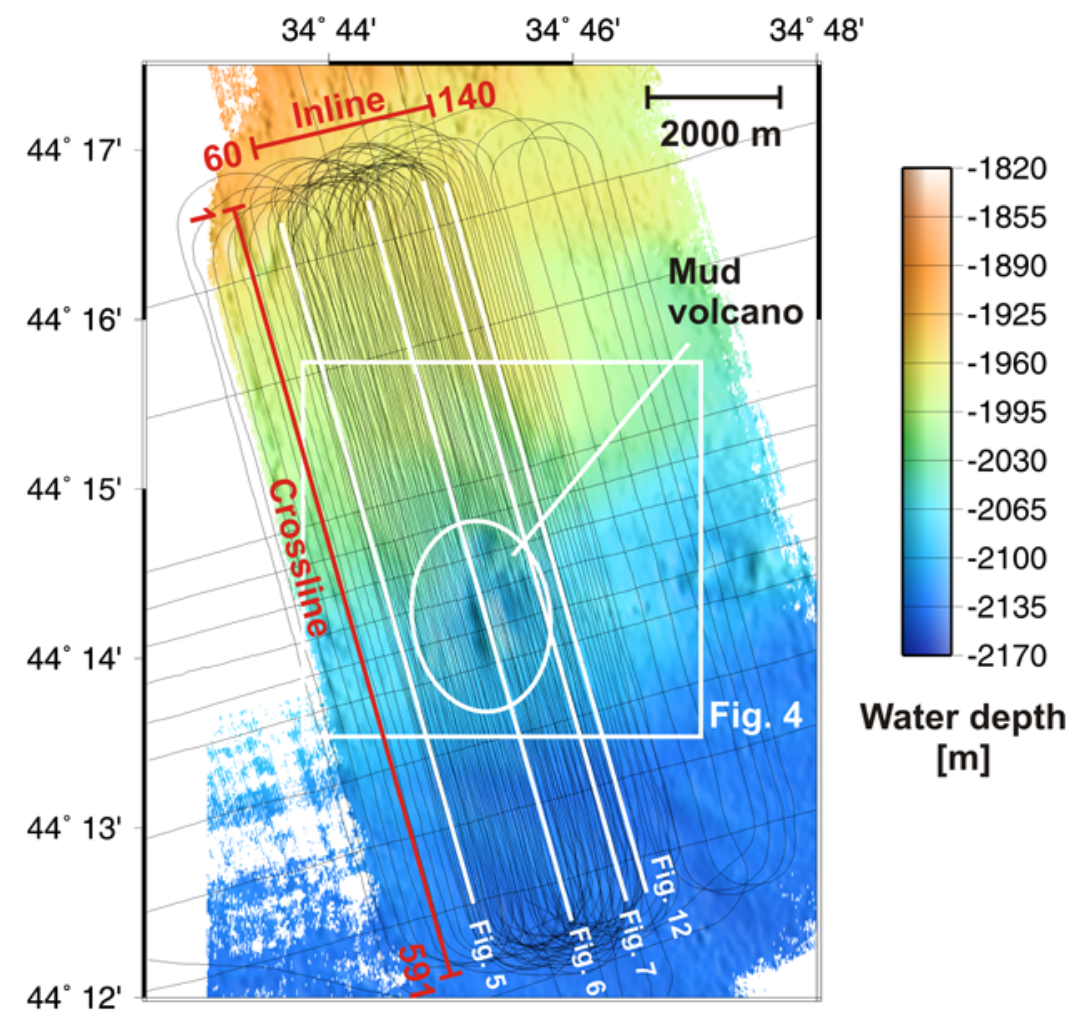

Figure 3. Bathymetric map of the 3-D survey area in the western Sorokin Trough based on $15.5 \mathrm{kHz}$ Krupp Atlas Hydrosweep data together with the seismic tracks of the 3-D grid. The white lines are shown in this paper.

and Shatsky Ridge along their flanks [Woodside et al., 1997]. The compressive deformation facilitates fluid/gas migration toward the seafloor and overpressured fluids lead to the formation of numerous mud volcanoes, which mostly evolve on the edges of the near-surface mud diapirs. On the basis of seismic studies, three types of mud volcanoes have been distinguished in the Sorokin Trough: most of the mud volcanoes are cone-shaped, some are collapse structures (pockmarks), and one, the Dvurechenskii mud volcano, is flat topped [Krastel et al., 2003]. Most mud volcanoes are located at the northern edges of the Tetyaev Rise and Shatsky Ridge (Figure 2).

[8] In the Sorokin Trough, gas hydrates were recovered from several mud volcanoes and above diapirs [Ginsburg et al., 1990; Bouriak and Akhmetjanov, 1998; Ivanov et al., 1998; Kenyon et al., 2002; Bohrmann et al., 2003]. The gas hydrates are believed to form local accumulations, and are controlled by mud volcanoes and can be related to zones of intensive fluid flow toward the seafloor [Ginsburg et al., 1990; Bouriak and Akhmetjanov, 1998]. Evidence for extensive fluid flow to the seafloor is the acoustic anomalies in seismic data, the formation of mud volcanoes and geochemical composition such as high gas saturation of the sediments and light carbon isotope content of carbonates [Ivanov et al., 1998]. In the Black Sea gas hydrates are stable below a water depth of $700 \mathrm{~m}$ [Ginsburg et al., 1990].

\section{Methods}

[9] The high-resolution multichannel seismic data presented in this paper were collected during Meteor cruise M52/1 in the early 2002. A GIGun with 0.41 chambers (main frequency 100$500 \mathrm{~Hz}$ ) towed at $1.4 \mathrm{~m}$ water depth was used along all seismic lines. Data were recorded by a $300 \mathrm{~m}$ long streamer section (SYNTRON) with 24 channels at a group distance of $12.5 \mathrm{~m}$. The streamer was kept at a water depth of $3 \mathrm{~m}( \pm 0.5 \mathrm{~m})$ by the usage of 9 birds (cable levelers). Magnetic compass readings in the birds allow the determination of the position of each hydrophone group. The data were digitally recorded at a sampling frequency of $4 \mathrm{kHz}$ over an interval of $3 \mathrm{~s}$. Positioning was based on GPS recordings. The seismic survey was divided into two parts. Initially, 44 seismic lines were shot as overview profiles to get information about the general structures and the 


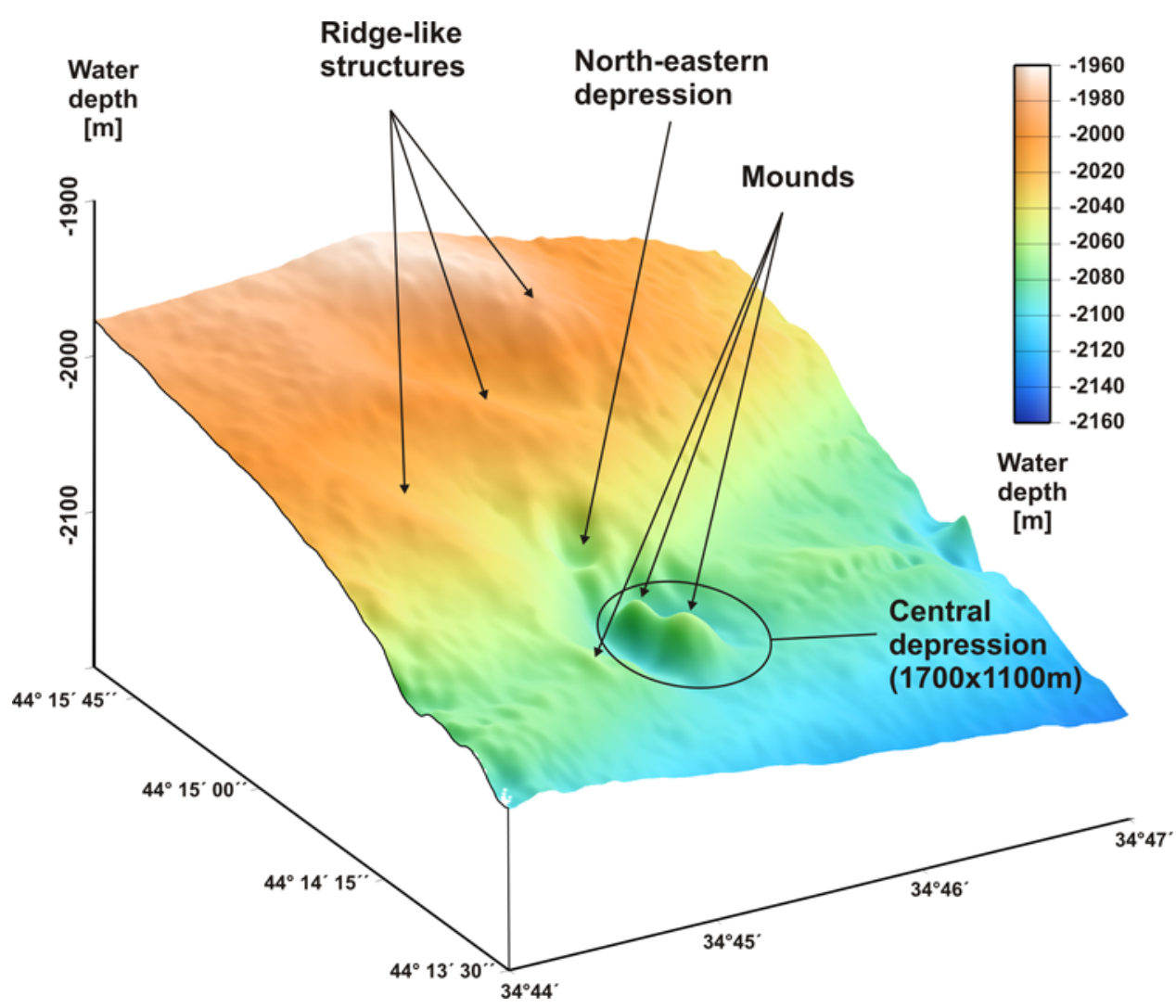

Figure 4. Three-dimensional bathymetric view of the slope within the 3-D area in the Sorokin Trough. The depression structure and the mounds of the Sevastopol mud volcano are well pronounced within the smooth morphology of the slope.

distribution of the mud volcanoes in the survey area. On the basis of these results, first interpreted by Krastel et al. [2003], a $2.5 \times 7.5 \mathrm{~km}$ large area around the Sevastopol mud volcano in the western Sorokin Trough was chosen for the threedimensional survey in order to resolve the structural variability observed in the overview lines (Figure 2), which are characterized by a complex pattern of buried diapiric ridges and sedimentary basins.

[10] Our 3-D acquisition geometry consists of a series of 81 parallel 2-D lines with a line spacing of $25 \mathrm{~m}$ (Figure 3). The lines are oriented in the NNW-SSE direction perpendicular to the strike direction of the diapiric ridges. Additionally, 24 profiles with a line separation of $50-100 \mathrm{~m}$ increase the width of the survey region to $\sim 6 \mathrm{~km}$ and 11 cross profiles were shot as connecting lines to the overview profiles.

[11] Geometry processing was done by custom software and includes the calculation of source and receiver positions, which was the basis for the calculations of offsets and the CMP binning. Residual lateral offsets between adjacent profiles binned on the same inline were adjusted. Statics caused by vertical movements of the streamer were corrected with help of the depth information from the birds. Afterward the 3-D seismic data were NMO corrected with a constant velocity of $1500 \mathrm{~m} / \mathrm{s}$, band pass frequency filtered with a frequency content of 55/110-600/800 and stacked at a Common Cell Gather distance of $12.5 \mathrm{~m}$ in the inline and $25 \mathrm{~m}$ in the crossline direction. The average cell coverage was about 7 . Finally, a FK-3D time migration at a constant velocity of $1500 \mathrm{~m} / \mathrm{s}$ was applied. Because of the relatively short streamer (300 m maximal offset) and water depths of more than $2000 \mathrm{~m}$ no velocity analysis was carried out. Locally low and irregular bin coverage along several inlines, particularly at the margins of the grid, and the limited crossline extension affect the quality of the 3-D migration. Only the central grid area, comprising inlines $60-140$, is nonproblematic for the migration aperture and hence was used for interpretation. With main frequencies of $120-150 \mathrm{~Hz}$ and maximum dip angles of only $4^{\circ}$ in the crossline direction, spatial aliasing is not a problem. During the processing the amplitude 


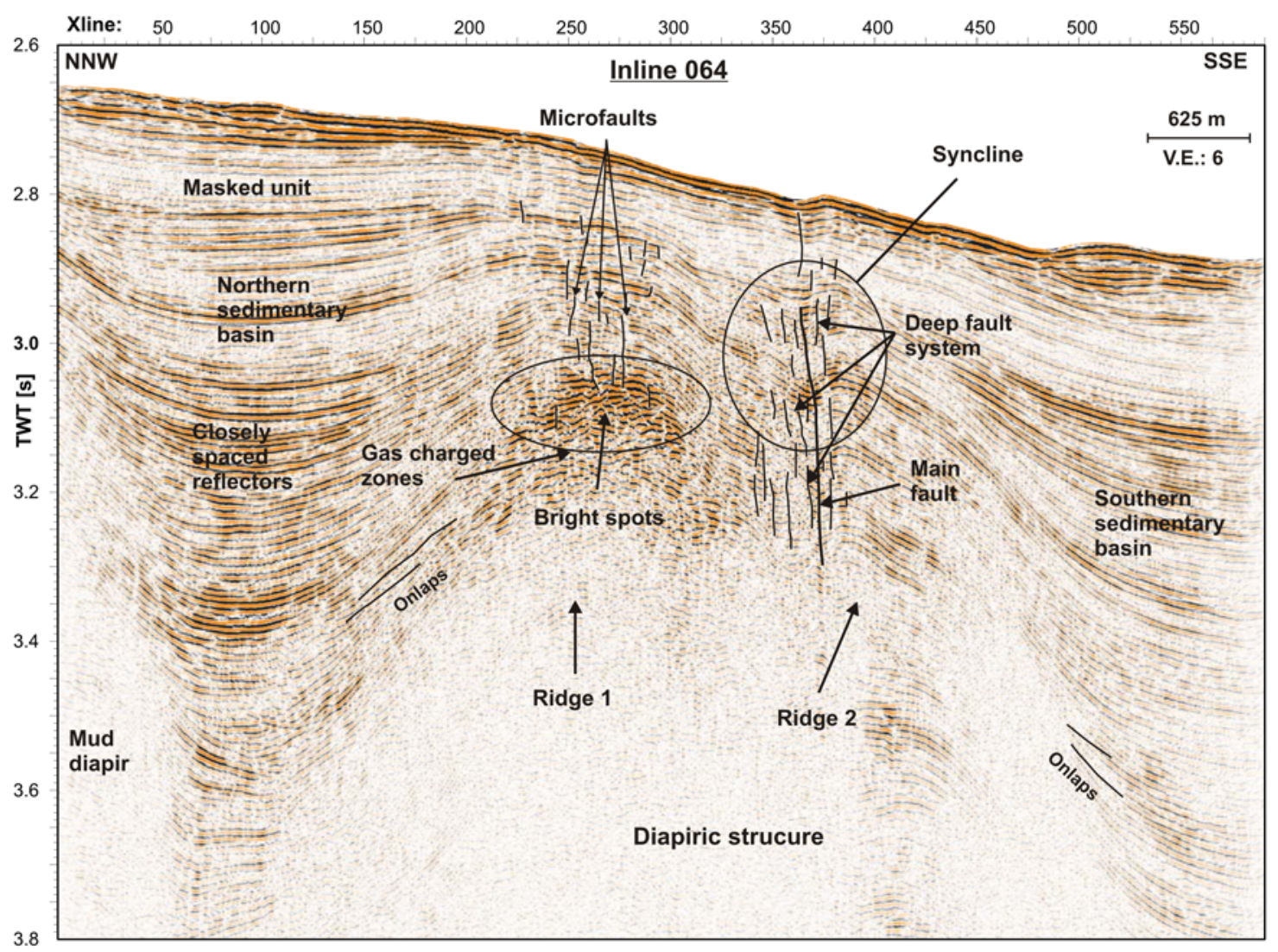

Figure 5. Time migrated seismic inline 064 at the western periphery of the 3-D grid. A deep fault system is developed between ridge 1 and ridge 2. Enhanced amplitude reflections (bright spots) are found above ridge 1. The location of the line is shown in Figure 3.

information was preserved and only spherical divergence was corrected.

[12] Bathymetric data were continuously obtained with the Krupp Atlas Hydrosweep system, using a frequency of $15.5 \mathrm{kHz}$ and 59 beams in a swath of $90^{\circ}$. Additionally, digital sediment echosounder data were permanently acquired by the Parasound/ParaDigMa System which uses a pulse with a dominant frequency of $4 \mathrm{kHz}$.

\section{Results}

\subsection{Bathymetry of the 3-D Seismic Survey}

[13] The 3-D study area is located at water depths of 1900-2150 $\mathrm{m}$ and characterized by a slope angle of about $0.5^{\circ}$ toward the southeast. The relief is low in general, but three smooth ridge-like structures occur in the north (Figure 4).

[14] The elliptically shaped Sevastopol mud volcano is composed of a $\sim 1700 \times 1100 \mathrm{~m}$ wide depression with a depth of about $25 \mathrm{~m}$ including two NNW-SSE trending cone-shaped mounds within its center. The southern cone has a height of $35 \mathrm{~m}$ and a diameter of about $500 \mathrm{~m}$, while the northern cone rises $25 \mathrm{~m}$ and extends $500 \mathrm{~m}$ in the $\mathrm{W}-\mathrm{E}$ direction and about $360 \mathrm{~m}$ in the N-S direction. The mounds show an asymmetrical shape with a maximal slope angle of $6.5^{\circ}$ at their southern flanks, while the slope angle of the northern flank is between $2.6^{\circ}$ and $4.5^{\circ}$. There is no significant relief within the depression except for the mounds (Figure 4). At the southwestern rim of the depression a third mound rises about $10 \mathrm{~m}$ above the surrounding seafloor with a diameter of $300 \times$ $200 \mathrm{~m}$. A second circular depression with a radius of $330 \mathrm{~m}$ and a maximum depth of $10-15 \mathrm{~m}$ is located at the northeastern margin of the mud volcano (Figure 4).

\subsection{Seismic Structure of the 3-D Area}

[15] On the basis of four inlines (Figures 5-7) the main structural features, i.e., the diapiric structure, the Sevastopol mud volcano, and the sedimentary 


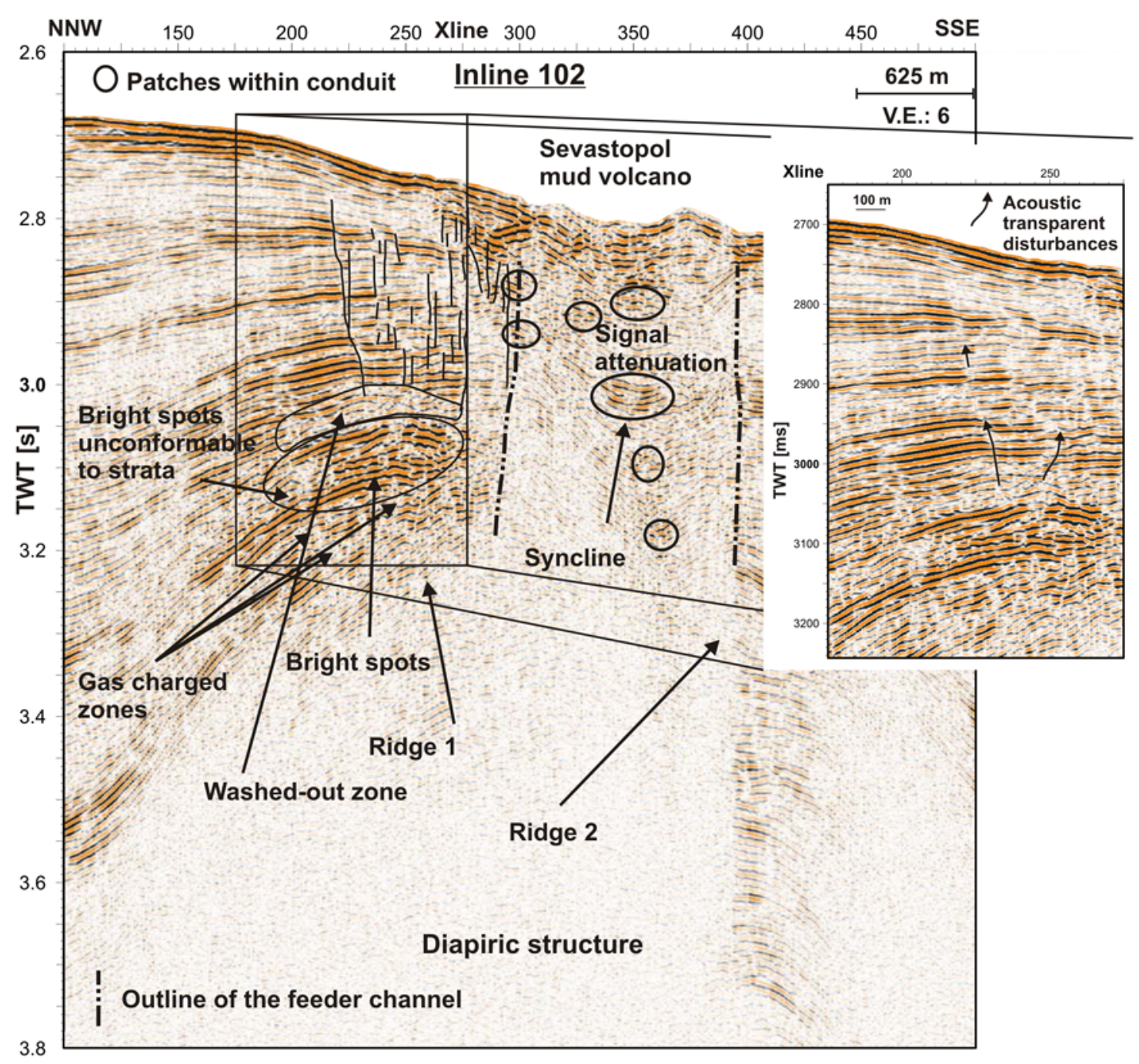

Figure 6. Time migrated section of seismic inline 102 in the central grid area. The Sevastopol mud volcano is formed above the fault system, where it is characterized by a depression with two mounds inside the depression. Beneath the mud volcano, a zone of signal attenuation reaches down to the diapir. The bright spots are located on the northern edge of ridge 1 . The inset shows an interpreted portion of the seismic section. The location of the line is shown in Figure 3.

basins, and their variability within the study area are described below. On Figure 8 a three-dimensional block of the survey area is shown, and on Figure 9 three time slices at depths of 2.95, 3.07 and $3.15 \mathrm{~s}$ TWT (two-way travel time) image the lateral changes of the subsurface structures.

\subsubsection{Diapiric Structure and Sevastopol Mud Volcano}

[16] The 3-D area is characterized by a complex buried diapiric structure with two ENE-WSW striking diapiric ridges (ridge 1 in the north and ridge 2 in the south), separated by a small syncline (e.g., Figure 5). The sediments in the western grid area are disrupted by a deep fault system with vertical offsets of several ms TWT (Figure 5). The main fault trends E-W parallel to the diapiric ridges and can be traced for more than $1 \mathrm{~km}$ from the western edge of the grid area to the central part. The tops of the diapiric ridges are located at a depth of about $400 \mathrm{~ms}$ TWT bsf (below seafloor) (Figures 5-7). With the exception of weak bulged reflections in the core of ridge 2, the diapiric structure is generally characterized by acoustic transparency (Figures 5-8). A package of highamplitude reflections (bright spots) occurs at about $300 \mathrm{~ms}$ TWT bsf just above and at the northwestern edge of ridge 1 . The bright spots have a thickness decreasing from $150 \mathrm{~ms}$ TWT in the west to $40-50 \mathrm{~ms}$ TWT in the east (Figures 5-7). The bright spots are characterized by chaotic reflection 


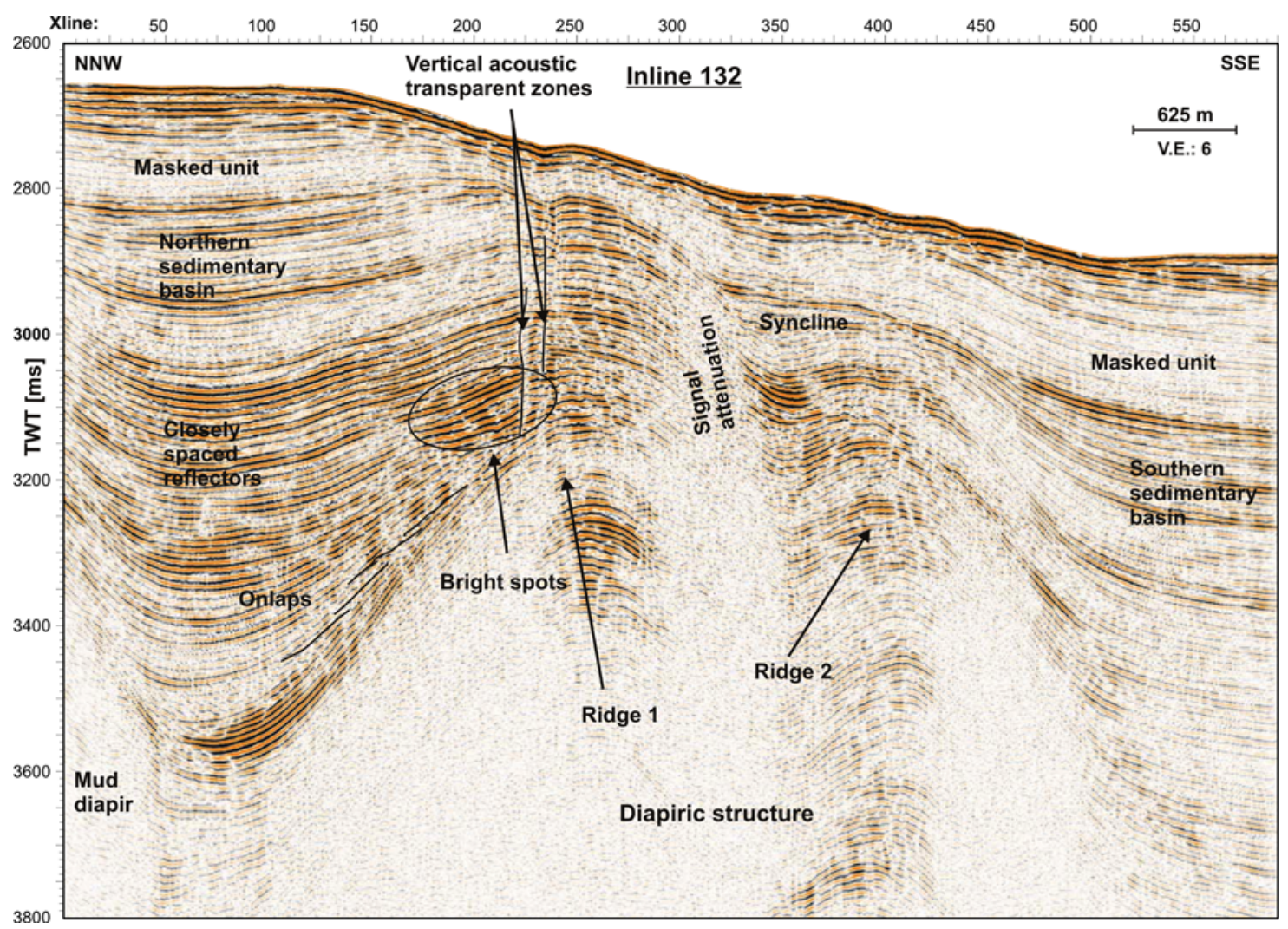

Figure 7. Time migrated seismic inline 132 in the eastern part of the 3-D grid. Bright spots are observed at the northern flank of ridge 1. The location of the line is shown in Figure 3.

patches, so that it is unclear whether they are conformable or unconformable to the surrounding strata (Figures 5-7).

[17] On the top of ridge 1, the bright spots are definitely conformable (Figures 5-7), but on the diapir flanks the reflections seem to crosscut the stratigraphic units (Figure 6). In the outermost eastern portion of the grid area the bright spot reflections are less chaotic and conformable with the strata at the onlap termination of the northern diapiric flank (Figure 7).

[18] In the central 3-D grid, the Sevastopol mud volcano is formed on the seafloor above the fault system developed between ridge 1 and ridge 2 . The seafloor of the central depression structure of the mud volcano is represented by a package of diffuse and disrupted medium amplitude reflection patches (Figure 6). The mounds located in the centre of the depression are characterized by a weak seafloor reflection and short washed-out inner reflections (Figure 6). Beneath the mud volcano, a zone of signal attenuation with a width similar to the diameter of the mud volcano can be traced down to the diapir and reveals only few discontinuous reflection patches inside (Figures 6 and 8).

\subsubsection{Sedimentary Basins}

[19] Two sedimentary basins, the northern and southern sedimentary basin, are separated by the diapiric structure and are filled with well-stratified parallel reflectors of laterally and vertically varying amplitudes (Figures 5-8). The lower sedimentary layers are onlapping on the flanks of the diapiric structure and the upper layers are bulged upward above the diapir. The sediments are generally characterized by units of weak amplitude reflections separated by closely spaced and continuous high-amplitude reflectors (e.g., Figures 5 and 7). Signal penetration is down to $3.8 \mathrm{~s}$ TWT (Figures $5-8$ ). In the northern basin the units of weak amplitude reflections have a $>$ thickness of 80-100 ms TWT, decreasing above the diapiric structure and increasing with the water depth in the southern basin from $130 \mathrm{~ms}$ in the west to $200 \mathrm{~ms}$ TWT in the east (Figures 5-8). Above ridge 2 the reflection amplitudes are weakened (e.g., Figures 5 and 7), while there are enhanced amplitude reflections above ridge 1, which are disrupted by numerous microfaults with a vertical offset of 4-5 ms TWT (Figures 5-8). Individual microfaults cannot be traced along ridge 1 , but represent local fractures laterally extending about $50-100 \mathrm{~m}$ 


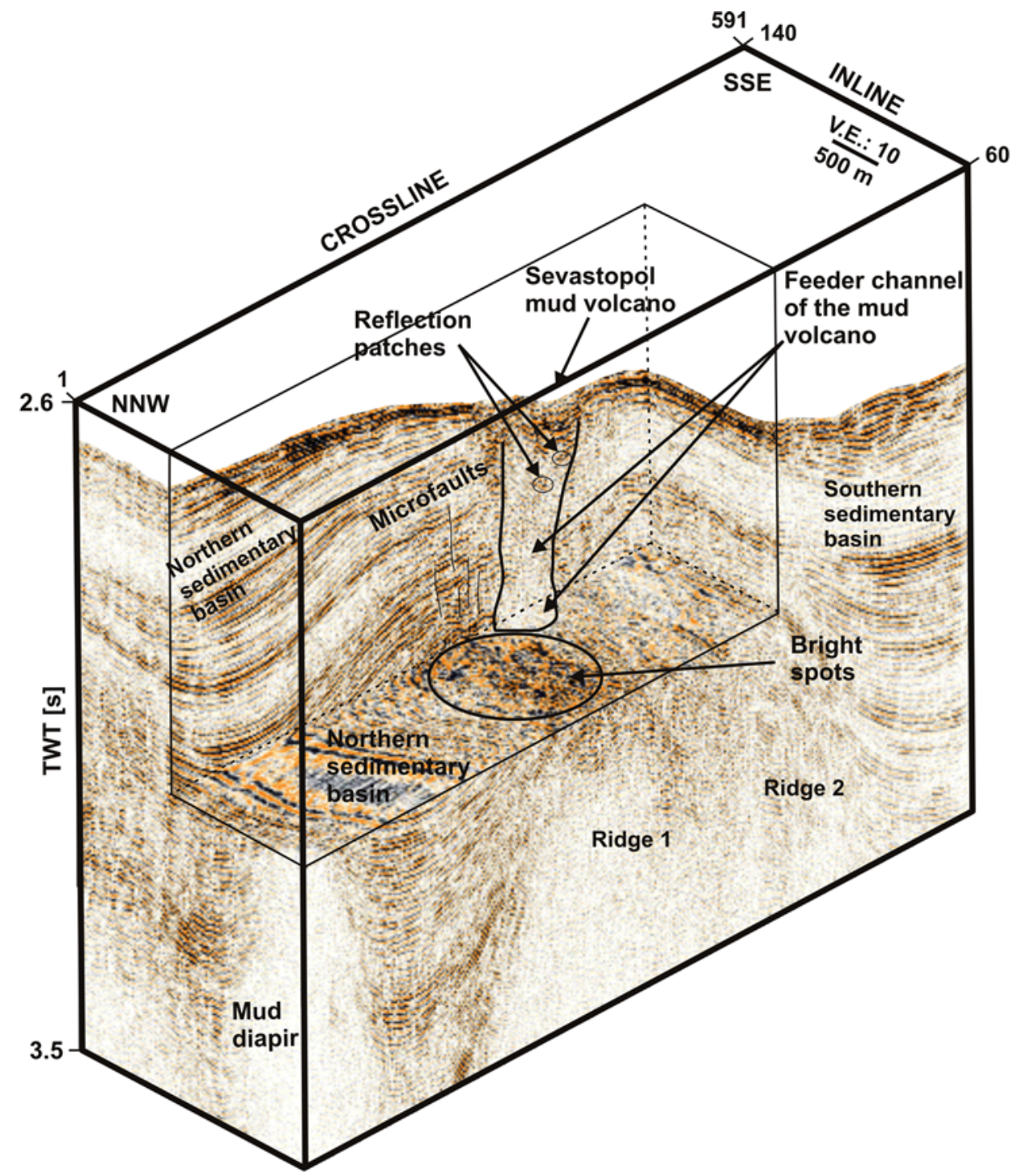

Figure 8. Three-dimensional block diagram of the survey area. The time slice crosses the bright spots and the feeder channel of the Sevastopol mud volcano at a depth of $3.09 \mathrm{~s}$ TWT. Two mud diapirs are imaged in the subsurface.

and only a few faults can be traced for more than $200 \mathrm{~m}$ parallel to ridge 1 .

[20] The syncline between ridge 1 and ridge 2 extends about $250 \mathrm{~m}$ in the NNW-SSE direction with a steep northern and moderately dipping southern flank; the syncline can be traced down to the diapir (Figures 5 and 7). In the western and the central grid area the syncline is characterized by irregular weak reflection patches disturbed by the deep fault system described above (Figure 5). In the eastern grid area the syncline contains continuous horizontal reflectors onlapping the sediments bulged above ridge 1 and continuing to the southern basin (Figure 7).

\subsection{Distribution of the Subsurface Structures}

[21] For a better understanding of the complex relationship of the structural features, the observed subsurface structures were mapped and are displayed together with the bathymetry collected during M52/1 cruise (Figure 10). The depth of the top of the bright spots bsf varies from 0.266 to 0.486 s TWT (Figure 10). Most bright spots are located at a depth between 300 and $400 \mathrm{~ms}$ TWT below seafloor with an average depth of $345 \mathrm{~ms}$ TWT bsf. The bright spots occur above the top of ridge 1 in the western part of the study area, but occur mainly on its northern flank further to the east (Figures 5-9). The bright spots occur at 


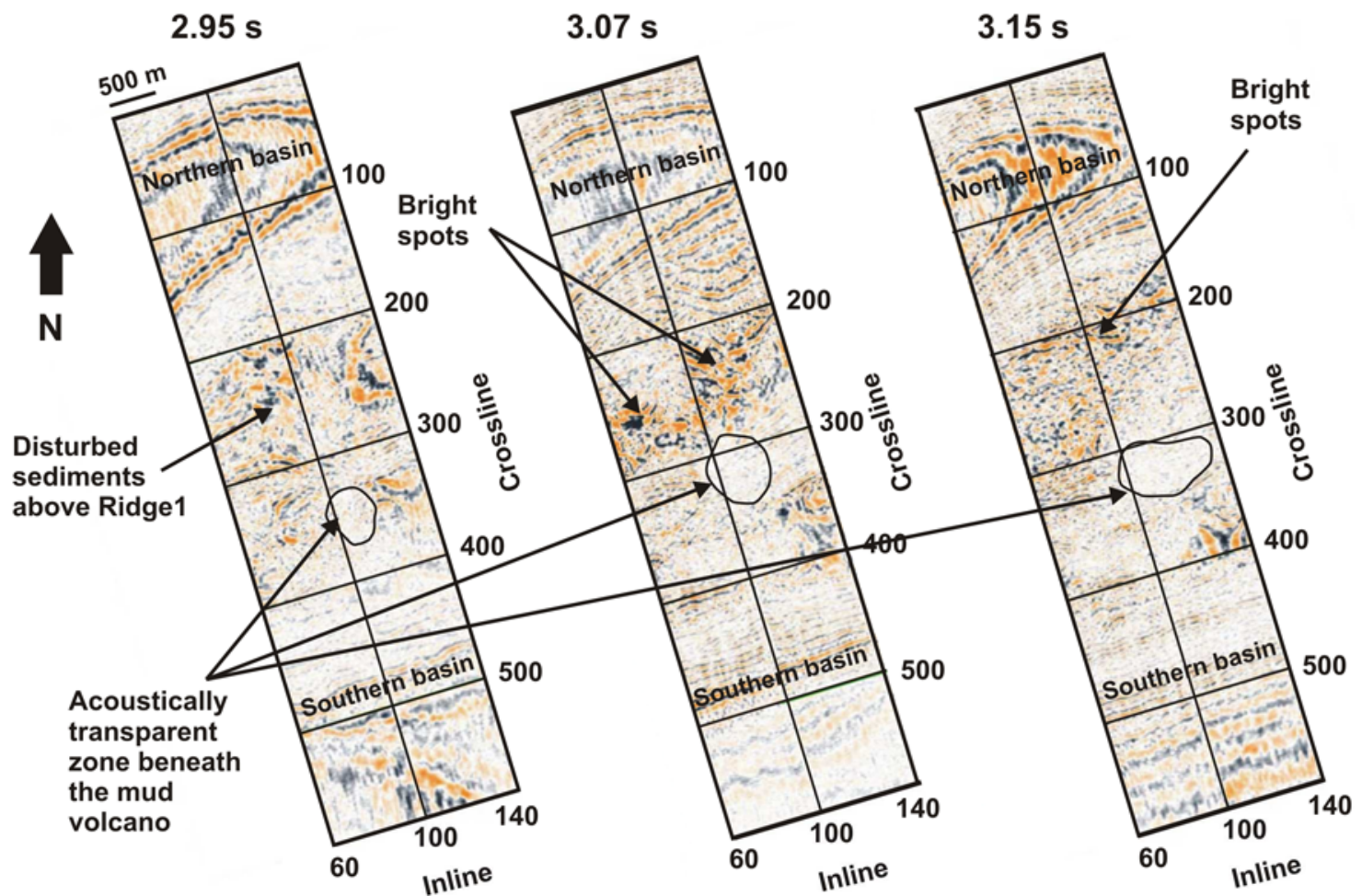

Figure 9. Three time slices from the 3-D seismic data cube calculated for the depths at $2.95 \mathrm{~s}, 3.07 \mathrm{~s}$ and $3.15 \mathrm{~s}$ TWT. Between the crosslines 200 and 300, chaotic reflections represent the sediments above ridge 1 disturbed by the microfaults at depth shallower than 2.998 ms TWT, while at greater depths the bright spots are distinctly imaged. The zone of signal attenuation beneath the mud volcano has a circular shape with a diameter that increases with depth.

relatively constant depth along the strike of the diapir, but their depth increases from the top of ridge 1 toward the northern basin (Figure 10). Two zones with anomalously shallow bright spots depth of less than $0.298 \mathrm{~s}$ TWT bsf are located above ridge 1 at the southwestern and southeastern edge of the bright spot area (red areas in Figure 10). Above the bright spots, acoustic anomalies were observed: particularly in the east, several vertical acoustic transparent zones run vertically from the top of the bright spots up to $200 \mathrm{~ms}$ TWT along the microfaults, partly reaching through the bright spots down to the diapir (Figures 6-8). These zones (blue zones in Figure 10) are cylindricalellipsoidal shaped with lateral dimensions of $275 \mathrm{~m} \times 250 \mathrm{~m}$.

[22] The mud volcano is located between ridge 1 and ridge 2. The zone of signal attenuation observed beneath the mud volcano has similar lateral dimensions as the mud volcano (Figures 6 and 10). The fault system developed between the diapiric ridges forms a $180-200 \mathrm{~m}$ wide zone striking in the ENE-WSW direction and can be traced from the western edge of the 3-D grid to the central part of the mud volcano, where the fault is lost because of the acoustic transparency beneath the Sevastopol mud volcano (Figure 10).

\section{Interpretation and Discussion}

\subsection{Evolution Model of the Sevastopol Mud Volcano}

[23] Most mud volcanoes in the Sorokin Trough, including the Sevastopol mud volcano, are associated with near-surface mud diapirs [Woodside et al., 1997; Krastel et al., 2003], which are related to the clays of the Oligocene-Miocene Maikopian Formation. The convergence between the Crimean Peninsula in the north and the buried Tetyaev and Shatsky Ridges in the south in combination with a thick overburden on top of the Maikop clays led to the protrusion of diapirs and diapiric ridges [Limonov et al., 1997]. Although our high-resolution seismic data do not resolve the base of the diapiric structures, we are convinced that the diapirs observed in the 3-D data set are related to the Maikop Formation. The clasts recovered from mud breccia samples at the nearby Dvurechenskii mud volcano have been correlated to the Maikopian Formation [Bohrmann et al., 2003]. The deep fault system 


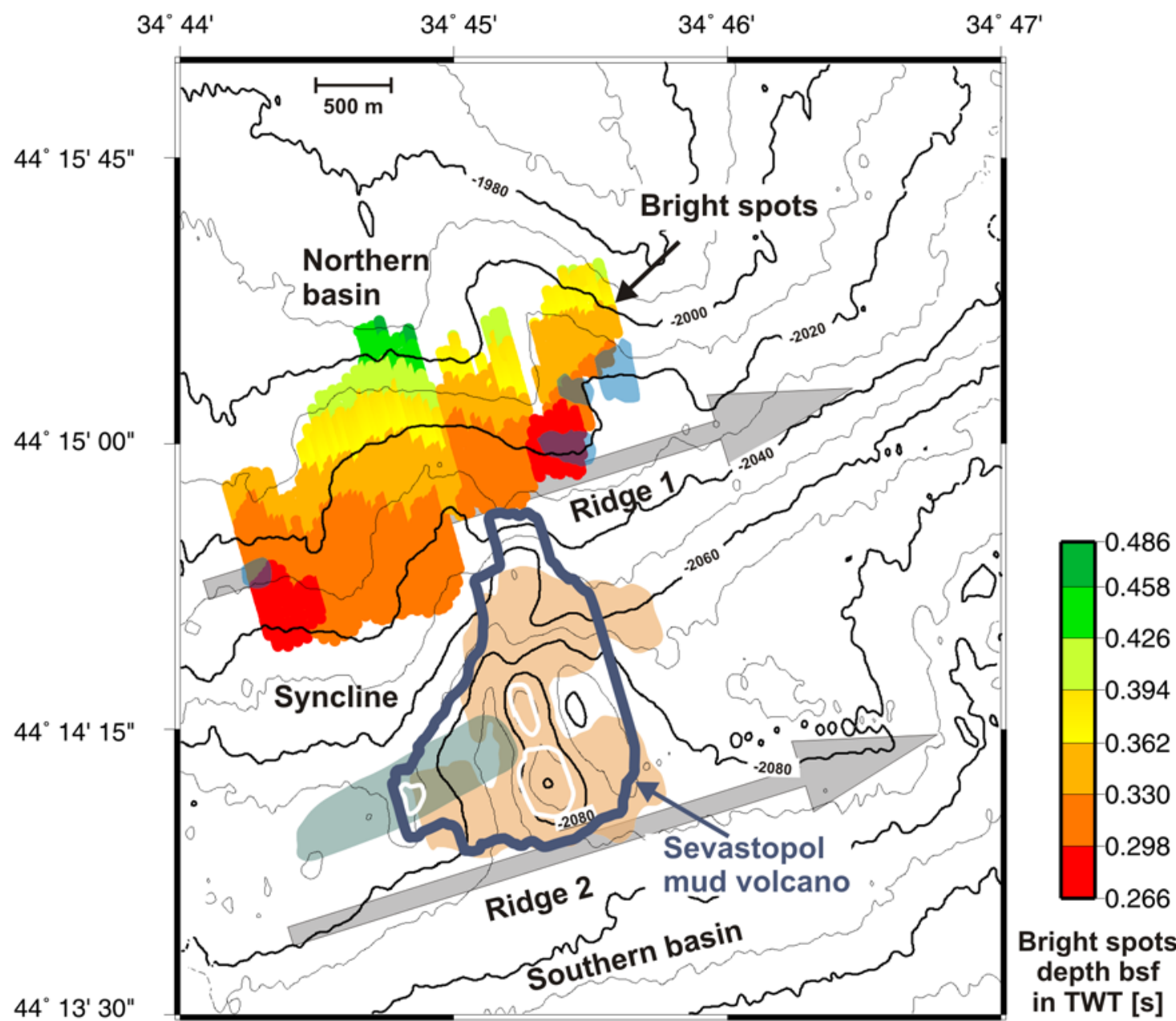

\section{Deep fault system between} the diapiric ridges

\section{Acoustic transparency beneath the mud volcano}

Vertical transparent zones along faults above Ridge 1

\section{Strike direction of the diapiric ridges}

Figure 10. Distribution of the main subsurface structures, i.e., the bright spots, the fault system and upward fluid migration pathways (transparent zones), mapped from the 3-D seismic survey. The white lines in the range of the mud volcano mark the mounds of the mud volcano. The color contours represent the uppermost bright spot reflectors in TWT [s] bsf.

developed between the diapiric ridges (ridge 1 and ridge 2) forming the complex near-surface diapiric structure located beneath the Sevastopol mud volcano acts as potential pathways for upward gas/fluid migration and is the most likely fluid flow pathway to supply the Sevastopol mud volcano. The development of the fault system is controlled by the diapirism (see below). The zone of signal attenuation surrounding the fault system may be caused by the presence of gas- and fluidsaturated material. Low signal, however, might be caused by other factors as well, such as roughness or steepness of the seafloor or lithological issues. The high relief at the mud volcano and carbonate precipitations, often associated with mud volcanoes due to anaerobic oxidation of methane, could lead to the signal loss beneath the mud volcano. Seismic overview profiles collected across numerous mud volcanoes in the Sorokin Trough and the Central Black Sea all show a zone of signal attenuation beneath the mud volcanoes [Bohrmann and Schenck, 2002; Krastel et al., 2003]. The observation that the zones of signal attenuation are often limited to a narrow zone beneath the top of the mud 
Phase 1 - Eastern grid area (a)

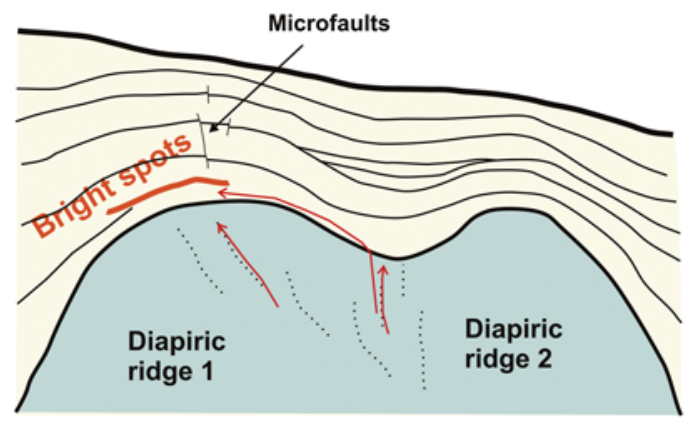

Intact diapiric structure with two ridges and a syncline between. Rising fluids along zones of weakness (dashed lines) within the diapir are trapped above Ridge 1.

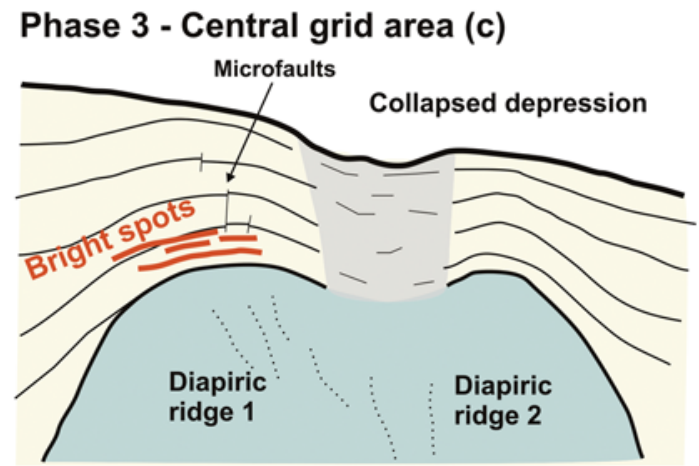

Depression structure of the mud volcano is formed by initial violent eruption due to overpressured fluids.

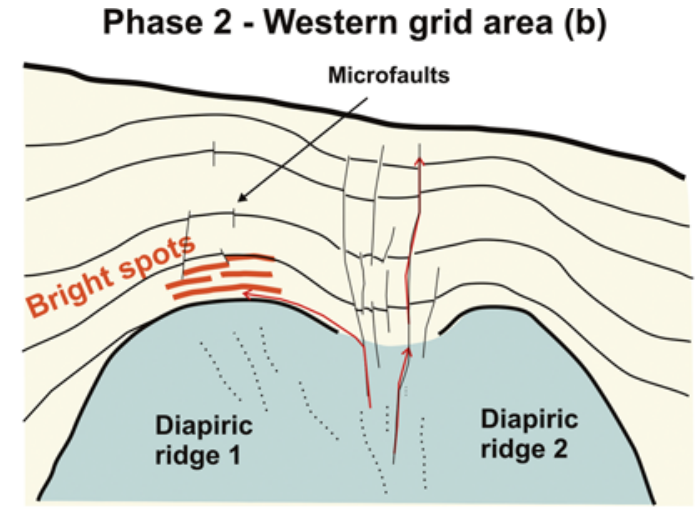

Development of fault system between the diapiric ridges facilitates fluid migration towards the seafloor.

Figure 11. Schematic illustration of the different phases of the evolution of the Sevastopol mud volcano and the subsurface structures as found in different areas of the 3-D grid. (a) The intact diapiric structure is observed in the eastern grid area. The red arrows indicate potential fluid migration pathways. (b) The deep fault system developed in the western grid area acts as potential pathway for gas/fluids. (c) The depression structure of the mud volcano most likely was formed by an explosive eruption due to overpressured fluids. (d) Fluids and fluidized mud rising along the fault system form the mud cones within the collapse depression of the mud volcano. For detailed explanations, see text.

volcano and do not cover the entire width of the mud volcano strongly supports our interpretation that the zones of signal attenuation are related to gas and not to imaging or lithological effects. Reflection patches observed within the conduit (e.g., Figure 6) also contradict signal loss due to the roughness or steepness of the flanks of the mud volcanoes. Hence this zone is interpreted as the feeder channel connecting the mud volcano with the diapir (Figures 6 and 8). As the given stratigraphy does not allow significant fluid migration toward the seafloor, we propose that the Sevastopol mud volcano is fed from the diapir by fluidized mud rising with gas and fluids along the fault system to the seafloor.

[24] On the basis of the 3-D images of the mud volcano we suggest a four-phase evolution model for the Sevastopol mud volcano (Figure 11).

[25] Phase 1 is the initial phase with the intact diapiric structure: The two diapiric ridges are separated by a syncline filled with more or less horizontal reflections (Figures 7 and 11a). Bright spots at the northern flank of ridge 1 indicate that upward gas and fluid migration occurs throughout the diapir into the strata, then they migrate parallel 
to the strata to the top of ridge 1 , where free gas accumulates and generates the bright spots. The development of the deep fault system between ridge 1 and ridge 2 during phase 2 is the first important stage in the evolution of the mud volcano and represents the incipient formation of the later feeder channel (Figures 5 and 11b). By the creation of the faults potential fluid migration pathways toward the seafloor are formed. The evolution of the faults is most likely associated with the diapirism and the compressional deformation. We suggest that the formation began along the steep southern flank of ridge 1. Different protrusion rates of the diapiric ridges, presumably a rapid protrusion of ridge 1, might have steepened its flank and lead to a vertical displacement of the ridges leading to the evolution of fractures. Otherwise, extension between the two ridges could lead to normal faults as well. It remains unclear, why the fault system is only developed in the western and not yet in the eastern grid area. Phases 3 and 4 comprise two formation mechanism of the mud volcano with different driving forces (Figures 11c and 11d). The morphological shape of mud volcanoes reflects the eruption mechanism and the properties of the extrusion products [e.g., Brown, 1990; Ivanov et al., 1996; Kopf, 2002]. The lower the viscosity of the extruded mud the larger and flatter the body. Highly permeable mud results in domes and pies with relatively steep slopes. High pore fluid pressure, caused by low permeability, might lead to violent eruptions [Dimitrov, 2002; Kopf, 2002; Yusifov and Rabinowitz, 2004]. The compressional tectonic deformation, the thick overburden and the low permeability of the mud diapir facilitate the generation of overpressured fluids in the Sorokin Trough, thus we suggest that the depression structure of the Sevastopol mud volcano was initially formed by an explosive eruption due to overpressured fluids (phase 3, Figure 11c). The hemipelagic sediments in the surroundings of the mud volcano allow less vertical fluid migration and low permeability layers or gas hydrate-saturated horizons act as traps for rising fluids leading to increased pore pressure and overpressured fluids. The bright spots above ridge 1 indicate the presence of trapped gas. Seal failure, when the pore fluid pressure exceeds the fracture pressure, results in violent eruptions and sudden release of fluids/ gas, forming collapse structures and calderas [Hovland et al., 1997]. Sedimentary layers disturbed after the collapse are represented by weak irregular and chaotic reflections within the conduit (Figure 6). Subsequent, quiet and effusive mud extrusions during phase 4 are believed to have formed the cones inside the depression (Figures 6 and 11d).

\subsection{Bright Spots at the Base of Gas Hydrate Stability Zone}

\subsubsection{Do the Bright Spots Indicate Free Gas and Represent the Phase Boundary of Gas Hydrate?}

[26] The Black Sea is known to contain enormous concentrations of gas in the marine sediments [e.g., Hunt and Whelan, 1978; Ivanov et al., 1998]. In the western Sorokin Trough numerous bright spots, observed either in the cores of anticlinal structures or at the updip terminations of strata with the diapirs at a relatively constant depth of $\sim 300 \mathrm{~ms}$ TWT bsf [Krastel et al., 2003], suggest the presence of free gas. Similarly, in our 3-D seismic survey area the high-amplitude reflection packages identified just above or at the updip termination of the strata with the northwestern flank of ridge 1 (Figures 10 and 12) are considered to represent bright spots related to free gas occurrences.

[27] Apart from gas, there are numerous further factors affecting seismic amplitudes, such as changes of sediment properties, effects of topography, scattering and artifacts due to processing. The latter can be excluded, because true amplitudes are imaged. We identified further abundant lateral and vertical amplitude variations in the data set which we do not attribute to gas, but the high-amplitude reflections described as bright spots above differ significantly: The so-called bright spots form a thick package of diffuse high-amplitude reflection patches and occur consistently above the diapir, while the other amplitude variations predominantly occur along one reflector. Analyzing the frequency content of seismic data can help to identify free gas in the sediments, because free gas absorbs the highfrequency component of the seismic energy [Taylor et al., 2000]. The abrupt decrease of the main frequencies from about $115 \mathrm{~Hz}$ above the bright spots to $\sim 95 \mathrm{~Hz}$ beneath within a range of $50 \mathrm{~ms}$ (Figure 13) therefore supports the presence of free gas.

[28] A polarity change of the seismic signal would be an additional tool to identify free gas, because the velocity decrease caused by free gas leads to a negative reflection coefficient [e.g., Max, 1990]. Unfortunately, the chaotic and patchy reflection pattern does not allow to determine the phase of the bright spots. We also need to keep in mind that no definite conclusions about the origin of ampli- 


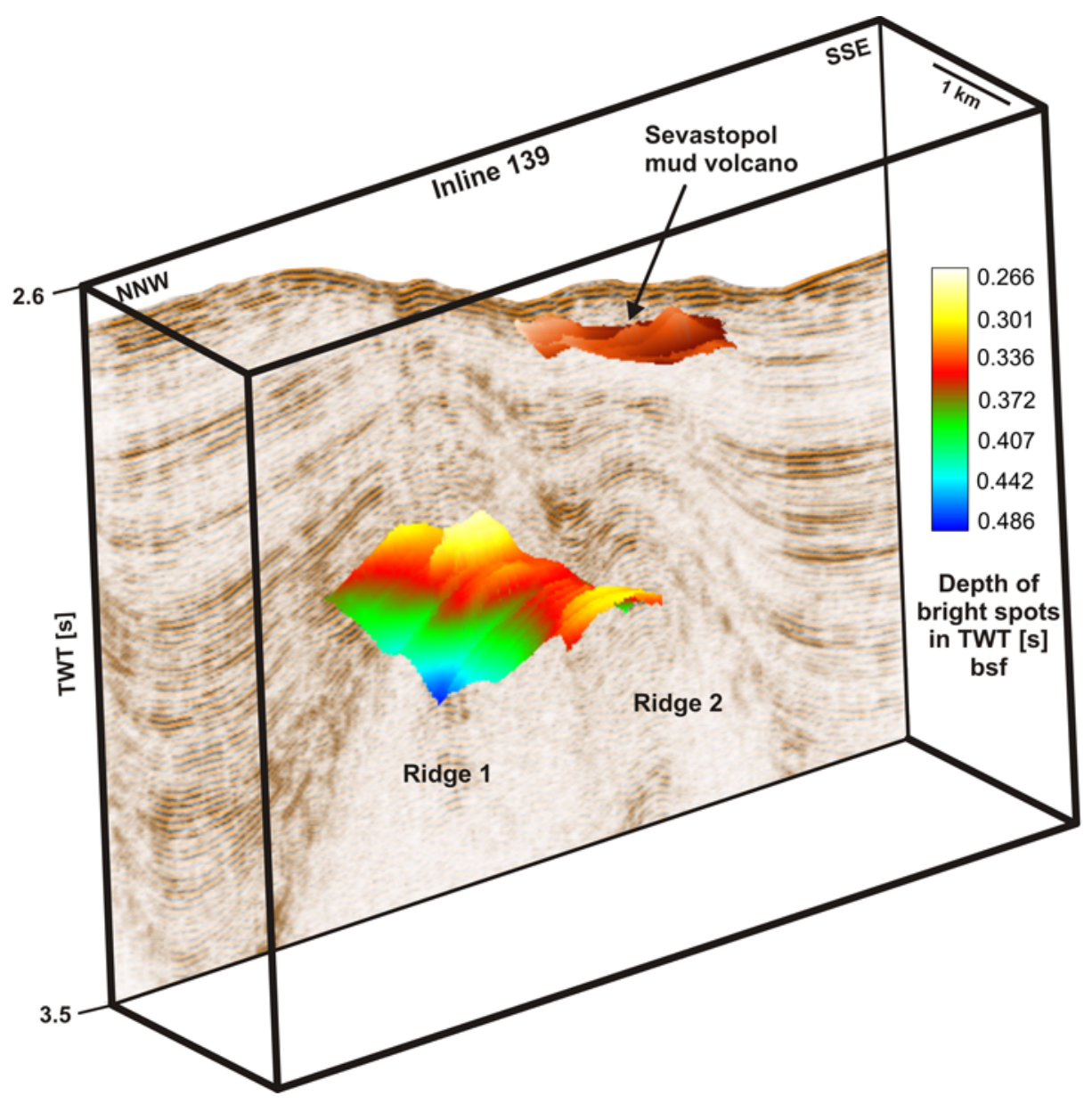

Figure 12. Three-dimensional image of the top of the bright spots in s TWT bsf in front of inline 139. The location of the seismic line is shown in Figure 3.

tude variations can be drawn on the basis of the reflection seismic methods alone, because interpretation is based on relative amplitudes changes. On the basis of the reflection characteristic of the bright spots and the observed decrease of frequency underneath, we attribute the bright spots to free gas occurrences. The enhanced reflection patches beneath the bright spots, as in particular observed in the western grid area, might present gas charged zones (e.g., Figures 5 and 6), which is a well known phenomenon of bright spots [Holbrook, 2001].

[29] Now, it is worth discussing the possible reasons for the trapped free gas. The flanks and the top of diapirs are typical locations for trapping gas and hence the observed bright spots could be interpreted as lithological or tectonic traps for free gas accumulation. The bright spots are found in a more or less constant subbottom depth and are independent of the stratigraphic layers, as it would be expected for a lithological gas trap. On inline 132 (Figure 7), the reflections occur at different stratigraphic layers than on inline 102 (Figure 6). Classic bright spots can occur at every depth, but in our data, the bright spots are limited to a narrow depth range and no bright spots are found at shallower depth. The depth of the bright spots is constant along the strike of the diapir and only varies in the N-S direction. On the basis of these observations we speculate that gas is not trapped at a specific layer but beneath the base of gas hydrate stability zone (BGHSZ) and we speculate, that the top of the bright spots represent the BGHSZ. In this scenario, gas hydrates above the bright spots act as seal to trap the gas beneath because of the low permeability of hydrate layers [White, 1979; Bangs et al., 1993; Pecher et al., 1996; Holbrook, 2001]. Indications for the presence of gas hydrates above the bright spots might be given by zones of washed-out reflections observed in the western grid area (Figure 6), as sediments containing gas hydrates can reduce the impedance contrast across sedimentary interfaces [Lee and Dillon, 2001; 


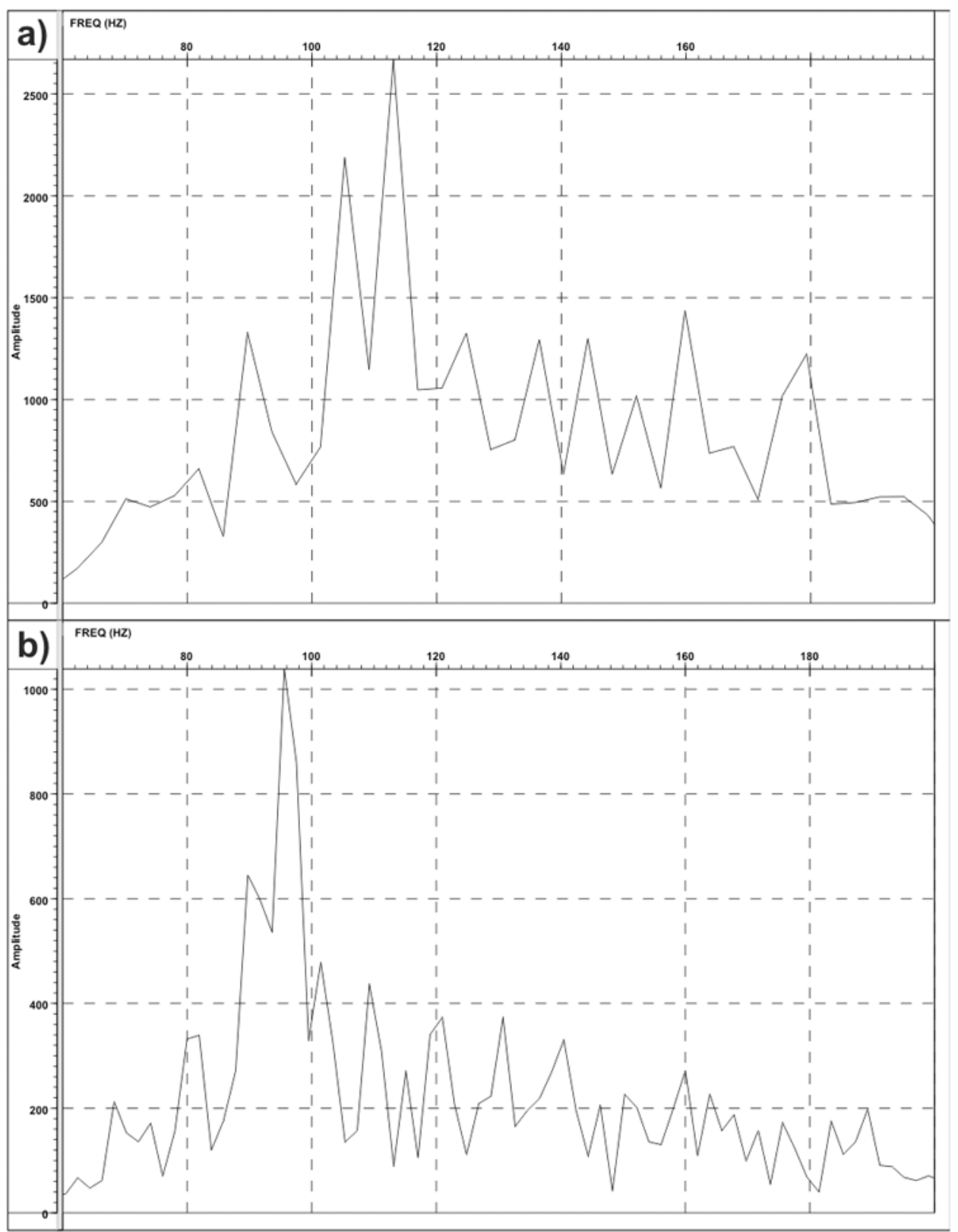

Figure 13. Frequency trace graph for inline 102, (a) above the bright spots at about $3.1 \mathrm{~s}$ TWT and (b) beneath the bright spots at about $3.15 \mathrm{~s}$ TWT. Above the bright spots the main frequency is $115 \mathrm{~Hz}$, decreasing abruptly to $95 \mathrm{~Hz}$ beneath the bright spots.

Holbrook et al., 2002]. This particularly applies to low concentrations of gas hydrates. In the next section we will discuss whether the bright spots might be related to the phase boundary of gas hydrate.

[30] During Meteor cruise M52/1 gas hydrates were sampled at adjacent mud volcanoes, e.g., at the Dvurechenskii, Yalta and Odessa mud volcanoes (Figure 2), though no gas hydrates were sampled at the Sevastopol mud volcano [Bohrmann et al., 2003]. Where gas hydrates are present, the base of the gas hydrate stability zone is often imaged as a bottom-simulating reflector (BSR), a high-amplitude reflector with a negative reflection coefficient, marking the transition between the high-velocity gas hydrate-bearing sediments and the underlying low-velocity sediments containing free gas [Shipley et al., 1979; Kvenvolden and Barnard, 1983; Minshull and White, 1989; Miller et al., 1991; Hyndman and Spence, 1992]. Some studies suggest that the BSR is generated because 


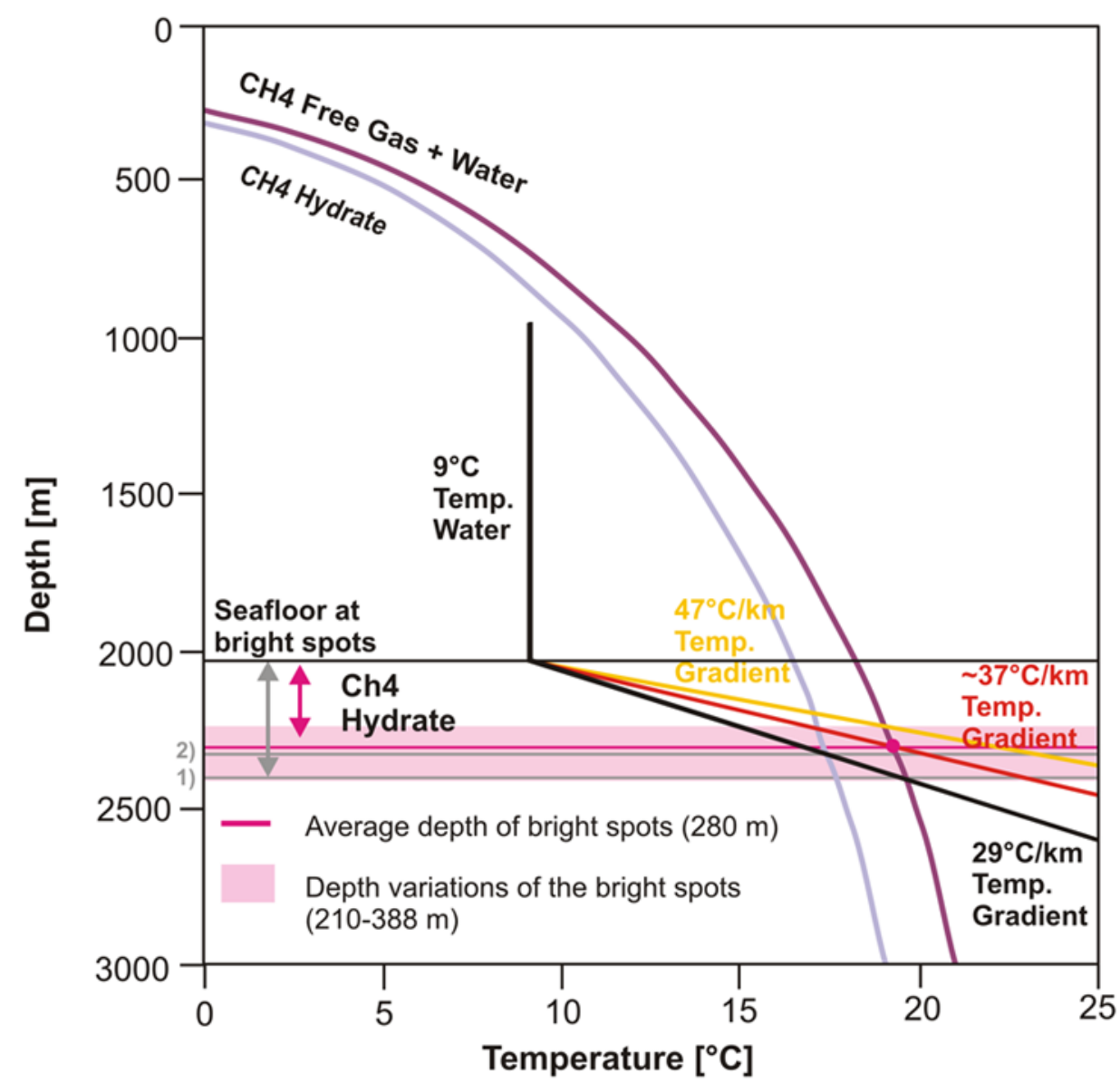

Hydrate stability curve at Black Sea chlorinity of $355 \mathrm{mM}$

Hydrate stability curve at pore water

Calculated depth of the BGHSZ with $9^{\circ} \mathrm{C}$ bottom water temperature and a

— temperature gradient of $29^{\circ} \mathrm{C} / \mathrm{km}$.

1) with Black Sea water chlorinity

2) with increased pore water chlorinity measured at DMV.

Figure 14. Gas hydrate stability field for a pure methane system calculated with (1) Black Sea water chlorinity (355 mM) and (2) pore water chlorinity of $900 \mathrm{mM}$ (measured in sediments at the Dvurechenskii mud volcano) (modified after Bohrmann et al. [2003] with kind permission of Springer Science and Business Media). The depth of the theoretical BGHSZ is calculated with a bottom water temperature of $9^{\circ} \mathrm{C}$ and a constant temperature gradient of $29^{\circ} \mathrm{C} / \mathrm{km}$. Assuming that the bright spots are related to the stability field of gas hydrate, the change in temperature gradient was inferred from the depth of the bright spots.

of the contrast between the high-velocity zone of gas hydrate-cemented sediments above and watersaturated sediments beneath [e.g., Hyndman and Davis, 1992]. Most velocity models, however, strongly suggest the presence of free gas beneath a BSR. Hence the widely accepted consensus is that a BSR reflection is caused by free gas trapped beneath the hydrate stability zone [Holbrook et al., 1996]. Despite the known presence of gas hydrates in the Sorokin Trough, a BSR is absent in all seismic sections.
[31] To control, whether the bright spots might be related to gas hydrate, we compared the measured depth of the bright spots with the theoretically calculated depth for the BGHSZ (Figure 14). The bright spots are located at a water depth of about $2020 \mathrm{~m}$ and occur at a depth range between 210 and 388 meter below seafloor (mbsf), calculated with an assumed sediment velocity of $1600 \mathrm{~m} / \mathrm{s}$. The following parameters were used to calculate the theoretical BGHSZ: (1) measured seafloor temperature of $9^{\circ} \mathrm{C}$ (reference station), (2) constant temperature gradient of $29^{\circ} \mathrm{C} \mathrm{km}^{-1}$ measured at a 
reference station in the Sorokin Trough, (3) pure methane system, and (4) Black Sea water chlorinity. On the basis of these assumptions the calculated depth of the BGHSZ at a water depth of about $2020 \mathrm{~m}$ is located at about $380 \mathrm{mbsf}$ (Figure 14).

[32] The comparison shows that the depth range of the bright spots coincides well with the approximate depth of the BGHSZ, but that most of the observed bright spots are located a little bit shallower than the expected BGHSZ (Figures 10, 12, and 14). Only the deepest bright spots, observed at the northern flank of ridge 1, coincide with the calculated depth. An uplift of the BGHSZ could be explained by a high thermal gradient or highsalinity waters, as observed, e.g., at the Dvurechenskii mud volcano [Bohrmann et al., 2003]. The depth variations of the bright spots will be discussed in the following chapter.

[33] As discussed above, we see local bright spots which we attributed to free gas occurrences trapped beneath the BGHSZ, but why do we not see a BSR in the study area? An explanation for the absence of a BSR is that the concentration of free gas and gas hydrate is very low, as suggested, e.g., for the Gulf of Mexico and portions of the Blake Ridge [Paull et al., 1996]. Thus the bright spots might represent fragments of a BSR, formed where fluid migration provides gas in sufficient amounts because of adequate fluid migration pathways, which are associated with the diapir and the mud volcano. This suggests that gas and gas hydrate occurrences in the Sorokin Trough are not widespread, but controlled by local gas/fluid migration. Another explanation might be that fluid flow is episodic, so that the BSR does not have time to establish at a particular depth. Then, the depth of the BSR changes with time, thus the transition from gas hydrate to gas may occur over a large depth range and hence cannot be imaged as a sharp interface. Episodic fluid flow would then also control the activity of the mud volcano.

\subsubsection{What Might Cause the Local Depth Variations of the BGHSZ?}

[34] In the previous chapter, we argued that the bright spots represent the BGHSZ, but the observed local depth variations of the bright spots still have to be explained. Changes of the factors controlling gas hydrate stability, i.e., temperature, pressure or salinity [e.g., Kvenvolden, 1993], can cause vertical movements of the BGHSZ. Stability of hydrate is primarily controlled by changes in temperature. Heat flow measurements in the Soro- kin Trough are very sparse, and the temperature gradient of $29^{\circ} \mathrm{C} \mathrm{km}^{-1}$ used for the calculation of the theoretical BGHSZ in the 3-D area was measured in an area without mud volcanoes. However, mud volcano areas are often characterized by increased heat flow values. As shown by Bohrmann et al. [2003], locally increased fluid flow in the Sorokin Trough does exist for the Dvurechenskii mud volcano (DMV) located at $2000 \mathrm{~m}$ water depth. Sediment temperatures of $16.5^{\circ} \mathrm{C}$ at the DMV in close contact to the bottom water temperature of $9^{\circ} \mathrm{C}$ suggest high fluid flux within the mud volcano [Bohrmann et al., 2003]. The high temperature measured at the DMV coincides with the maximum temperature for the methane hydrate stability at this depth [Bohrmann et al., 2003]. No heat flow measurements exist for the Sevastopol mud volcano, but we expect higher heat flow values as well. The upward flow of warm fluids associated with the Sevastopol mud volcano leads to an uplift of the isotherms [e.g., von Huene and Pecher, 1999], and could have uplifted the BGHSZ to the depth of the bright spots. Assuming that the bright spots represent the BGHSZ, geothermal gradients inferred from the depths of the bright spots show that an increased temperature gradient of almost $37^{\circ} \mathrm{C} / \mathrm{km}$ would explain the shallowing of the BGHSZ to $280 \mathrm{mbsf}$, representing the observed average depth of the bright spots (Figure 14). The shallowest bright spots with a depth of about 210 mbsf then could be caused by a thermal gradient of $47^{\circ} \mathrm{C} / \mathrm{km}$ (Figure 14). Furthermore the depth variations of the bright spots observed particularly in the NNW-SSE direction could be explained by local variations of the thermal gradient. Considering the stability field of gas hydrate on Figure 14, the depth variations could be explained by changes of the temperature gradient between $29^{\circ} \mathrm{C}$ and $47^{\circ} \mathrm{C} / \mathrm{km}$. Variations of the thermal gradient might be caused by variable fluid flow which we would expect in nearby a diapir/ mud volcano system. If the bright spots represent the gas hydrate phase boundary, their depth bsf, which is constant along the strike of ridge 1 , but shallows from the flank toward the top (Figures 10 and 12), suggests high fluid flow along the top of ridge 1 , decreasing toward the northern basin. The points of shallowest bright spots (Figures 10 and 12) might therefore be related to locally focused fluid flow. A constant depth of the bright spots, as observed in the ENE-WSW direction, then means a constant depth of the gas hydrate phase boundary in the strike direction of the diapiric ridge. The highest thermal gradients occur in the direct vicinity of the mud volcano, with values up to $47^{\circ} \mathrm{C} / \mathrm{km}$. 


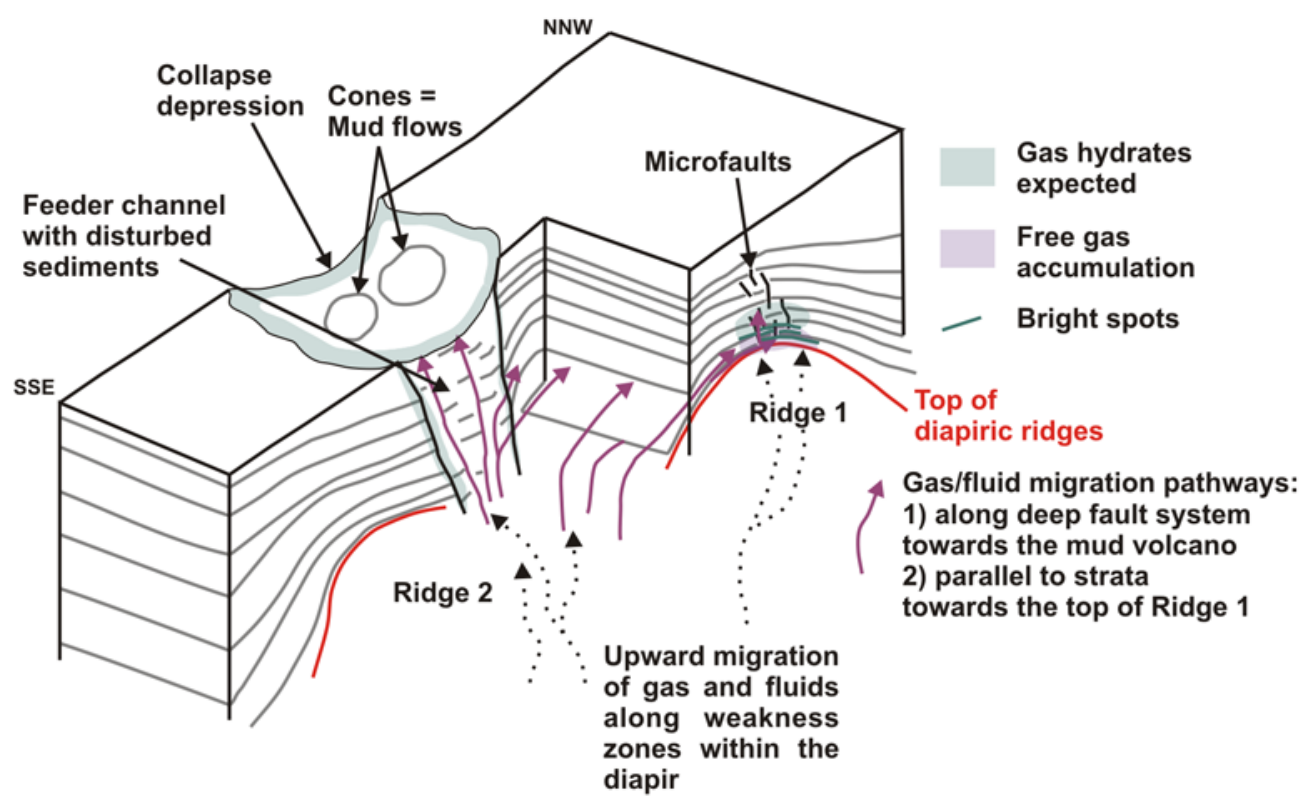

Figure 15. Schematic model of the subsurface structures in the diapir-mud volcano system and suggested gas/fluid migration pathways. Gas hydrates are expected where focused fluid flow occurs, i.e., toward the top of ridge 1 and in the surrounding of the mud volcano and its feeder channel.

Similarly high values, found by Kutas et al. [2004] in the northern Black Sea and even higher values measured at the Dvurechenskii mud volcano [Bohrmann et al., 2003], show that these values are reasonable for a mud volcano area.

[35] Another aspect influencing the stability of gas hydrate is the salinity of pore waters, which often includes high-salinity fluids in the range of mud volcanoes. Increased salinity would shift the gas hydrate stability field to lower temperatures [Kvenvolden, 1993; Taylor et al., 2000], and hence also would lead to a shallowing of the BGHSZ. Measured $\mathrm{Cl}^{-}$concentrations of $810-$ $900 \mathrm{mM}$ at the Dvurechenskii mud volcano indicate the expulsion of high-salinity fluids, which are considered to be formed by diagenetic processes during burial [Bohrmann et al., 2003; Aloisi et al., 2004]. At a thermal gradient of $29^{\circ} \mathrm{C} / \mathrm{km}$, salinity as high as measured at the DMV would uplift the theoretical BGHSZ into a depth of $300 \mathrm{~m}$, which almost coincides with the average depth of the bright spots $(280 \mathrm{~m})$ (Figure 14). Unfortunately, neither heat flow nor $\mathrm{Cl}^{-}$measurements exist for the Sevastopol mud volcano. Hence we only can speculate what causes the shallow depth of the BGHSZ. Probably a combination of both, the upward flow of warm high-salinity waters, leads to the uplift of the BGHSZ and local variations of fluid flow could explain the depth variations of the bright spots.

\subsection{Fluid and Gas Migration}

[36] If the bright spots represent the BGHSZ as suggested above the distribution of the bright spots implies local gas occurrences, above which gas hydrate may occur above ridge 1. A model of potential fluid migration pathways associated with the mud volcano/diapir system and indications for gas/gas hydrate occurrences is shown in Figure 15. The most likely fluid migration pathways are faults observed above ridge 1 and between the ridges and directly linked to the diapirism. Furthermore, highly permeable bulged sediments at the diapiric flanks act as potential fluid migration pathways toward the top of the diapir (Figure 15). The source of the fluids is thought to be located within the Maikop clay diapirs, released because of the transformation of smectite into illite under high temperature and pressure conditions. Kholodov [1983] determined the depth boundary between smectite and illite in the eastern Kuban Trough to be about $3.7 \mathrm{~km}$. The low permeability of the Maikop clay and the sedimentary cover force overpressured fluids, which are most likely released at zones of weakness developed in the compressional tectonic regime, and migrate throughout the diapirs into the strata. Migration pathways within the diapir could not be identified because of the acoustic transparency of the homogeneous Maikop clays. The deep fault system between the diapiric ridges is considered to be the continuation of fractures within the 
diapir and is suggested to control the fluid migration toward the Sevastopol mud volcano. The wellstratified hemipelagic sediments of the basins prohibit significant vertical upward fluid migration, but from the feeder channel gas/fluids might migrate laterally into the surrounding strata (Figure 15). The upward bulged sediments above ridge 1 facilitate lateral gas/fluid migration along highly permeable stratigraphic layers toward the top of ridge 1, where the gas accumulates generating the bright spots (Figure 15).

[37] Besides the generation of strong reflections due to increased seismic impedance contrast, the occurrence of free gas in seismic sections is often characterized by acoustic transparency due to the attenuation of acoustic energy, which is especially pronounced in high-resolution seismic data [Max, 1990; Taylor et al., 2000]. Vertically acoustic void zones with a width of up to $225 \times 200$ m indicate upward gas/fluid migration along the microfaults above ridge 1 into the GHSZ (Figures 7 and 10). The combination that these acoustic void zones are related to the faults suggests that faults are the main potential pathways for gas/fluids toward the seafloor. The vertically transparent zones are located within the GHSZ and as mentioned above, signal attenuation can also be due to the presence of gas hydrate, but the attenuation from gas hydratebearing sediments is significantly lower than from free gas bearing sediments [Taylor et al., 2000]. Furthermore, we do not think that the zones are transparent because of signal loss in the overburden, as we observe high-amplitude reflections underneath. The interpretation of seismic amplitudes, however, has to be handled carefully. In the eastern grid area in particular, such acoustic void zones are observed (Figure 7), indicating that fluid flow is focused here, whereas in the western and central grid area fluid flow is evenly spread, but less focused. Acoustically transparent disturbances observed along numerous microfaults (e.g., Figure 6) are interpreted as pathways for gas/fluid migration as well. The microfaults above ridge 1 have most likely been developed during the diapiric growth and may allow sufficient amounts of gas to migrate into the gas hydrate stability zone, resulting in the formation of gas hydrates if water is present. The observation that increased permeability of the microfaults does not prevent gas accumulation supports that not a lithological trap but gas hydrates filling the fractures and sediments above act as seal for free gas. On the basis of the distribution of the fluid migration pathways, which are mainly faults and bulged strata, and bright spots, gas hydrate formation is expected above and at the northwestern flank of ridge 1 as well as in the area surrounding the mud volcano and the feeder channel (Figure 15).

\section{Conclusions}

[38] Few 3-D seismic investigations of mud volcanoes have been documented yet, such as offshore Nigeria [Graue, 2000], in the Caspian Sea [Davies and Stewart, 2005], and in the Gulf of Cádiz [Masson and Berndt, 2006]. We present a first 3-D seismic data set of a mud volcano (Sevastopol mud volcano) in the Sorokin Trough, Black Sea. Numerous mud volcanoes were identified in the Sorokin Trough, and the Sevastopol mud volcano is a representative for collapse structures. Collapse structures are known from other areas as well, such as the Central Black Sea and the Mediterranean Ridge [e.g., Ivanov et al., 1996], but have not been studied in 3-D until now. The new 3-D images give detailed information about the three-dimensional structure of the collapsed Sevastopol mud volcano and its spatial relationship to the near-subsurface diapiric ridges and potential fluid migration pathways. We could show a direct linkage between the mud diapirism, potential fluid migration along fractures and the mud volcano system. On the basis of the morphological features, an evolution model has been suggested for the Sevastopol mud volcano. The seismic data show that the evolution of the Sevastopol mud volcano is related to a diapiric structure with two ridges (ridge 1 and ridge 2) located beneath the mud volcano. The analyses show that faults acting as main potential fluid migration pathways play an important role for the evolution of the mud volcano. Fluid migration along the deep fault system, developed during the growth of the diapirs in a compressional tectonic regime between ridge 1 and ridge 2 , feeds the mud volcano from the diapir. The well-bedded hemipelagic sediments of the basins surrounding the mud volcano inhibit significant vertical fluid migration and provide suitable traps for gas/fluids. An evolution model established for the Sevastopol mud volcano suggests that trapped overpressured fluids induced a violent explosion after seal failure, leading to a sudden release of gas and mud, and creating the collapse depression of the Sevastopol mud volcano. Permeability of the collapsed sediments is increased allowing subsequent effusive fluid and mudflow extrusion, which formed the cones inside of the depression. 
[39] High-amplitude reflections (bright spots) indicate the accumulation of free gas above and at the flanks of ridge 1 . Gas/fluids might migrate laterally from the feeder channel into the surrounding strata. Permeable upward bulged layers act as migration pathways to the diapiric top where gas/fluids are trapped and imaged as bright spots. The depth of the bright spots almost coincides with the calculated approximate depth of the BGHSZ. As the bright spots are independent of the strata and their depth is constant along the strike of the diapiric ridge and only slightly increases at its northern flank, we suggest that the bright spots represent the BGHSZ. Gas hydrates are likely present above this depth and may act as a seal to trap the gas. Microfaults above ridge 1 act as fluid migration pathways into the GHSZ supplying the gas hydrate reservoir. Warm fluids rising toward the mud volcano might explain the shallower depth of the bright spots with respect to the calculated theoretical BGHSZ. Assuming that the bright spots represent the BGHSZ, the average depth of the Bright Spots (280 mbsf) suggests an increased temperature gradient of almost $37^{\circ} \mathrm{C} / \mathrm{km}$. The depth variations of the bright spots indicate that the BGHSZ is strongly controlled by fluid flow. Changes of the temperature gradient from $29^{\circ} \mathrm{C} / \mathrm{km}$ to $47^{\circ} \mathrm{C} / \mathrm{km}$ would explain the observed variations in depth. Furthermore, threefold enhanced salinity pore fluids might uplift the BGHSZ into the depth of the bright spots, but chlorinity has not be measured at the Sevastopol mud volcano. We suggest that a combination of both, the upward flow of warm highsalinity fluids leads to an uplift of the BGHSZ represented by the bright spots. Fluid flow probably occurs episodically controlling the activity of the mud volcano and inhibiting the generation of a BSR.

\section{Acknowledgments}

[40] Our research was carried out within the MARGASCH project and funded by grants from the Deutsche Forschungsgemeinschaft $(\mathrm{Kr} 2222 / 4)$. We thank the crew and the participating scientists of the Meteor cruise M52/1 for their hard work and assistance in data acquisition.

\section{References}

Aloisi, G., M. Drews, K. Wallmann, and G. Bohrmann (2004), Fluid expulsion from the Dvurechenskii mud volcano (Black Sea) part I. Fluid sources and relevance to Li, B, Sr, I and dissolved inorganic nitrogen cycles, Earth Planet. Sci. Lett., 225, 347-363.

Andreev, V. (1976), The Crimean and Caucasian foredeeps in the Sea (in Russian), Izv. Akad. Nauk SSSR Ser. Geol., 11, $130-133$.
Bangs, N. L. B., D. S. Sawyer, and X. Golovchenko (1993), Free gas at the base of the gas hydrate zone in the vicinity of the Chile triple junction, Geology, 21, 905-908.

Belousov, V. V., et al. (1988), Structure and evolution of the earth's crust and upper mantle of the Black Sea, Bol. Geofis. Teor. Appl., 30, 109-196.

Bohrmann, G., and S. Schenck (2002), GEOMAR Cruise Report M52/1, MARGARSCH, RV Meteor, marine gas hydrates of the Black Sea, GEOMAR, Kiel, Germany.

Bohrmann, G., et al. (2003), Mud volcanoes and gas hydrates in the Black Sea: New data from Dvurechenskii and Odessa mud volcanoes, Geo Mar. Lett., 23, 239-249.

Bouriak, S. V., and A. M. Akhmetjanov (1998), Origin of the gas hydrate accumulations on the continental slope of the Crimea from geophysical studies, in Gas Hydrates: Relevance to World Margin Stability and Climate Change, edited by J.-P. Henriet and J. Mienert, Spec. Publ. Geol. Soc. London, 137, 215-222.

Brown, K. M. (1990), Nature and hydrogeologic significance of mud diapirs and diatremes for accretionary systems, J. Geophys. Res., 95, 8969-8982.

Cloething, S., G. Spadini, J. D. Van Wees, and F. Beekman (2003), Thermo-mechanical modelling of Black Sea Basin (de)formation, Sediment. Geol., 156, 169-184.

Davies, R. J., and S. A. Stewart (2005), Emplacement of giant mud volcanoes in the South Caspian Basin: 3D seismic reflection imaging of their root zones, J. Geol. Soc., 162, $1-4$.

Dewey, J. F., W. C. Pitman, W. B. F. Ryan, and J. Bonnin (1973), Plate tectonics and the evolution of the alpine system, Geol. Soc. Am. Bull., 84, 3137-3180.

Dimitrov, L. I. (2002), Mud volcanoes-the most important pathway for degassing deeply buried sediments, Earth Sci. Rev., 59, 49-76.

Dimitrov, L. I. (2003), Mud volcanoes - A significant source of atmospheric methane, Geo Mar. Lett., 23, 155-161.

Finetti, I., G. Bricchi, A. Del Ben, M. Pipan, and Z. Xuan (1988), Geophysical study of the Black Sea, Bol. Geofis. Teor. Appl., 30, 197-324.

Ginsburg, G. D., V. L. Ivanov, and V. A. Soloviev (1984), Natural gas hydrates of the world's oceans (in Russian), in Oil and Gas Content of the World's Oceans, pp. 141-158, PGO Sevmorgeologia, St. Petersburg, Russia.

Ginsburg, G. D., A. N. Kremlev, M. N. Grigor, G. V. Larkin, A. D. Pavlenkin, and N. A. Saltykova (1990), Filtrogenic gas hydrates in the Black Sea (21st voyage of the research vessel Evpatoriya), Sov. Geol. Geophys., 31, 101-152.

Golmshtok, A. Y., L. P. Zonenshain, A. A. Terekhov, and R. V. Shainurov (1992), Age, thermal evolution and history of the Black Sea Basin based on heat flow and multichannel reflection data, Tectonophysics, 210, 273-293.

Graue, K. (2000), Mud volcanoes in deepwater Nigeria, Mar. Pet. Geol., 17, 959-974.

Guliyev, I. S., and A. A. Feizullayev (1997), All About Mud Volcanoes, Nafta Press, Baku.

Holbrook, W. S. (2001), Seismic studies of the Blake Ridge: Implications for hydrate distribution, methane expulsion, and free gas dynamics, in Natural Gas Hydrates: Occurrence, Distribution, and Detection, Geophys. Monogr. Ser., vol. 124, edited by C. K. Paull and W. P. Dillon, pp. 235-256, AGU, Washington, D. C.

Holbrook, W. S., H. Hoskins, W. T. Wood, R. A. Stephen, and D. Lizarralde (1996), Methane hydrate and free gas on the Blake Ridge from vertical seismic profiling, Science, 273, $1840-1843$. 
Holbrook, W. S., A. R. Gorman, M. Hornbach, K. L. Hackwith, D. Nealon, D. Lizarralde, and I. A. Pecher (2002), Seismic detection of marine methane hydrate, Leading Edge, 21(7), 686-689.

Hovland, M., A. Hill, and D. Stokes (1997), The structure and geomorphology of the Dashgil mud volcano, Azerbaijan, Geomorphology, 21, 1-15.

Hunt, J., and J. Whelan (1978), Dissolved gases in the Black Sea sediments, Initial Rep. Deep Sea Drill. Proj., 42, 661665.

Hyndman, R. D., and E. E. Davis (1992), A mechanism for the formation of methane hydrate and seafloor bottom simulating reflectors by vertical fluid expulsion, J. Geophys. Res., 97, 7025-7041.

Hyndman, R. D., and G. D. Spence (1992), A seismic study of methane hydrate marine bottom simulating reflectors, J. Geophys. Res., 95(B5), 6683-6698.

Ivanov, M. K., A. M. Limonov, and T. C. E. van Weering (1996), Comparative characteristics of the Black Sea and Mediterranean Ridge mud volcanoes, Mar. Geol., 132, 253-271.

Ivanov, M. K., A. M. Limonov, and J. M. Woodside (1998), Extensive deep fluid flux through the sea floor on the Crimean continental margin (Black Sea), in Gas Hydrates: Relevance to World Margin Stability and Climate Change, edited by J.-P. Henriet and J. Mienert, Spec. Publ. Geol. Soc. London, $137,195-213$

Kenyon, N. H., M. K. Ivanov, A. M. Akhmetzhanov, and G. G. Akhmanov (2002), Geological processes in the Mediterranean and Black seas and North East Atlantic. Preliminary results of investigations during the TTR-11 cruise of RV Professor Logachev, Tech. Ser., 62, 89 pp., Intergovt. Oceanogr. Comm., Paris.

Kholodov, V. N. (1983), Post-sedimentation Transformations in Elisional Basins (One Example of the East Near Caucasus) (in Russian), 152 pp., Nauka, Moscow.

Kopf, A. J. (2002), Significance of mud volcanism, Rev. Geophys., 40(2), 1005, doi:10.1029/2000RG000093.

Krastel, S., V. Spiess, M. K. Ivanov, W. Weinrebe, G. Bohrmann, and P. Shashkin (2003), Acoustic images of mud volcanoes in the Sorokin Trough, Black Sea, Geo Mar. Lett., 23, $230-$ 238

Kutas, R. I., S. I. Paliy, and O. M. Rusakov (2004), Deep faults, heat flow and gas leakage in the northern Black Sea, Geo Mar. Lett., 24, 163-168.

Kvenvolden, K. A. (1993), Gas hydrates: Geological perspective and global change, Rev. Geophys., 31, 173-187.

Kvenvolden, K. A., and L. A. Barnard (1983), Gas hydrates of the Blake Outer Ridge, Site 533, Deep Sea Drilling Project Leg 76, Initial Rep. Deep Sea Drill. Proj., 76, 353-365.

Lee, M. W., and W. P. Dillon (2001), Amplitude blanking related to the pore-filling of gas hydrates in sediments, Mar. Geophys. Res., 22, 101-109.

Limonov, A. F., T. C. E. van Weering, N. H. Kenyon, M. K. Ivanov, and L. B. Meisner (1997), Seabed morphology and gas venting in the Black Sea mud volcano area: Observation with the MAK-1 deep-tow sidescan sonar and bottom profiler, Mar. Geol., 137, 121-136.

Masson, D. G., and C. Berndt (2006), RRS Charles Darwin Cruise 178, 14 Mar-11 Apr 2006, 3D acquisition over mud volcanoes in the Gulf of Cádiz and submarine landslides in the Eivissa Channel, western Mediterranean Sea, Cruise Rep. 3, 39 pp., Natl. Oceanogr. Cent., Southampton, U. K.

Max, M. D. (1990), Gas hydrate and acoustically laminated sediments: probable environmental cause of anomalously low acoustic-interaction bottom loss in deep ocean sediments, Rep. 9235, 68 pp., Nav. Res. Lab., Washington, D. C.
Milkov, A. V. (2000), Worldwide distribution of submarine mud volcanoes and associated gas hydrates, Mar. Geol., 167, 29-42.

Milkov, A. V., R. Sassen, T. V. Apanasovich, and F. G. Dadashev (2003), Global gas flux from mud volcanoes: A significant source of fossil methane in the atmosphere and the ocean, Geophys. Res. Lett., 30(2), 1037, doi:10.1029/2002GL016358.

Miller, J. J., M. W. Lee, and R. von Huene (1991), An analysis of a seismic reflection from the base of a gas hydrate zone, offshore Peru, AAPG Bull., 75, 910-924.

Minshull, T., and R. S. White (1989), Sediment compaction and fluid migration in the Makran accretionary prism, J. Geophys. Res., 94, 7387-7402.

Nikishin, A. M., M. V. Korotaev, A. V. Ershov, and M.-F. Brunet (2003), The Black Sea basin: Tectonic history and Neogene-Quaternary rapid subsidence modeling, Sediment. Geol., 156, 149-168.

Okay, A. I., A. M. C. Sengor, and N. Görür (1994), Kinematic history of the opening of the Black Sea and its effect on the surrounding regions, Geology, 22, 267-270.

Paull, C. K., et al. (1996), Proceedings of the Ocean Drilling Program, Initial Reports, vol. 164, Ocean Drill. Program, College Station, Tex.

Pecher, I. A., T. A. Minshull, S. C. Singh, and R. von Huene (1996), Velocity structure of a bottom simulating reflector offshore Peru: Results from full waveform inversion, Earth Planet. Sci. Lett., 139, 459-469.

Rangin, C., A. G. Bader, G. Pascal, B. Ecevitoglu, and N. Görür (2002), Deep structure of the Mid Black Sea High (offshore Turkey) imaged by multi-channel seismic survey (BLACKSIS cruise), Mar. Geol., 182, 265-278.

Robinson, A. G., J. H. Rudat, C. J. Banks, and R. L. F. Wiles (1996), Petroleum geology of the Black Sea, Mar. Pet. Geol., 13(2), 195-223.

Shipley, T., M. Houston, and R. Buffer (1979), Seismic reflection evidence for the widespread occurrence of possible gas hydrate horizons on continental slopes and rises, $A A P G$ Bull., 63, 2204-2213.

Soloviev, V., and G. D. Ginsburg (1994), Formation of submarine gas hydrates, Bull. Geol. Soc. Den., 41, 86-94.

Spadini, G., A. Robinson, and S. Cloetingh (1996), Western versus eastern Black Sea tectonic evolution: Pre-rift lithsopheric controls on basin formation, Tectonophysics, 266, $139-154$

Taylor, M. H., W. P. Dillon, and I. A. Pecher (2000), Trapping and migration of methane associated with the gas hydrate stability zone at the Blake Ridge Diapir: New insights from seismic data, Mar. Geol., 164, 79-89.

Tugolesov, D. A., A. S. Gorshkov, L. B. Meisner, V. Soloviev, and E. M. Khakhalev (1985), Tectonics of the MesozoicCenozoic Deposits of the Black Sea (in Russian), Nedra, Moscow.

von Huene, R., and I. A. Pecher (1999), Neotectonics and the origins of BSRs along the Peru margin, Earth Planet. Sci. Lett., 166, 47-55.

White, R. S. (1979), Gas hydrate layer trapping free gas in Gulf of Oman, Earth Planet. Sci. Lett., 42, 114-120.

Woodside, J. M., M. K. Ivanov, and A. F. Limonov (1997), Neotectonics and fluid flow through seafloor sediments in the Eastern Mediterranean and Black Seas. Parts I and II, UNESCO IOC Tech. Ser., 48, 224 pp., Intergovt. Oceanogr. Comm., UNESCO, Paris

Yusifov, M., and P. D. Rabinowitz (2004), Classification of mud volcanoes in the South Caspian Basin, offshore Azerbaijan, Mar. Pet. Geol., 21, 965-975. 